\title{
Global prevalence and incidence of traumatic spinal cord injury
}

This article was published in the following Dove Press journal:

Clinical Epidemiology

23 September 2014

Number of times this article has been viewed

\section{Anoushka Singh* \\ Lindsay Tetreault* \\ Suhkvinder Kalsi-Ryan \\ Aria Nouri \\ Michael G Fehlings}

Toronto Western Research Institute, Toronto Western Hospital, Toronto, Ontario, Canada

*These authors contributed equally to this paper
Correspondence: Michael G Fehlings Division of Neurosurgery, Toronto Western Hospital, 399 Bathurst St Suite 4WW-449, Toronto Ontario M5T2S8, Canada

Tel +4l6 6035072

Fax 4166035298

Email michael.fehlings@uhn.ca
Background: Spinal cord injury (SCI) is a traumatic event that impacts a patient's physical, psychological, and social well-being and places substantial financial burden on health care systems. To determine the true impact of SCI, this systematic review aims to summarize literature reporting on either the incidence or prevalence of SCI.

Methods: A systematic search was conducted using PubMed, MEDLINE, MEDLINE in process, EMBASE, Cochrane Controlled Trial Register, and Cochrane Database of Systematic Reviews to identify relevant literature published through June 2013. We sought studies that provided regional, provincial/state, or national data on the incidence of SCI or reported estimates of disease prevalence. The level of evidence of each study was rated using a scale that evaluated study design, methodology, sampling bias, and precision of estimates.

Results: The initial search yielded 5,874 articles, 48 of which met the inclusion criteria. Forty-four studies estimated the incidence of SCI and nine reported the prevalence, with five discussing both. Of the incidence studies, 14 provided figures at a regional, ten at a state or provincial level and 21 at a national level. The prevalence of SCI was highest in the United States of America (906 per million) and lowest in the Rhone-Alpes region, France (250 per million) and Helsinki, Finland (280 per million). With respect to states and provinces in North America, the crude annual incidence of SCI was highest in Alaska ( 83 per million) and Mississippi (77 per million) and lowest in Alabama (29.4 per million), despite a large percentage of violence injuries $(21.2 \%)$. Annual incidences were above 50 per million in the Hualien County in Taiwan (56.1 per million), the central Portugal region ( 58 per million), and Olmsted County in Minnesota (54.8 per million) and were lower than 20 per million in Taipei, Taiwan (14.6 per million), the Rhone-Alpes region in France (12.7 per million), Aragon, Spain (12.1 per million), Southeast Turkey (16.9 per million), and Stockholm, Sweden (19.5 per million). The highest national incidence was 49.1 per million in New Zealand, and the lowest incidences were in Fiji (10.0 per million) and Spain (8.0 per million). The majority of studies showed a high male-to-female ratio and an age of peak incidence of younger than 30 years old. Traffic accidents were typically the most common cause of SCI, followed by falls in the elderly population.

Conclusion: This review demonstrates that the incidence, prevalence, and causation of SCI differs between developing and developed countries and suggests that management and preventative strategies need to be tailored to regional trends. The rising aging population in westernized countries also indicates that traumatic SCI secondary to falls may become an increasing public health challenge and that incidence among the elderly may rise with increasing life expectancy.

Keywords: SCI, causation, epidemiology 


\section{Introduction}

Spinal cord injury (SCI) is a traumatic event that results in disturbances to normal sensory, motor, or autonomic function and ultimately impacts a patient's physical, psychological, and social well-being. ${ }^{1-3}$ The management of SCIs requires significant health care resources and can place a substantial financial burden on patients, their families, and the community. ${ }^{3}$ These costs are largely due to a need for highlevel acute care in the short term and associated secondary complications that occur in the long term. ${ }^{4}$ To improve injury management, it is necessary to quantify the incidence and prevalence of SCI to better understand rates of occurrence and delineate ways of prevention. Furthermore, this knowledge enables health care providers to estimate both the cost and psychosocial burden of this disease and the resources required for its management.

The economic impact of SCI on health care providers and on the system has become an increasingly important topic. According to Krueger et al, the estimated lifetime economic burden associated with SCI in Canada ranges from CAD $\$ 1.47$ million for a person with incomplete paraplegia to $\$ 3.03$ million for one with complete tetraplegia. ${ }^{4}$ These estimates include complications in the early surgical phase, such as wound infections and displaced instrumentation; emergency readmissions; and long-term complications, including pressure ulcers, bladder and bowel dysfunction, neuropathic pain, and respiratory problems. Annually, the estimated economic burden associated with SCI in Canada is $\$ 2.67$ billion ( $\$ 1.57$ billion in direct costs and $\$ 1.10$ billion in indirect costs) and includes costs associated with hospitalizations ( $\$ 0.17$ billion, or $6.5 \%$ of total costs), health care provider visits ( $\$ 0.18$ billion, or $6.7 \%$ ), equipment and home modifications ( $\$ 0.31$ billion, or $11.6 \%$ ) and attendant care $(\$ 0.87$ billion, or $32.7 \%){ }^{4}$

Three previous reviews were conducted to compare incidence and prevalence of SCIs in different countries and to outline causation of injuries in various geographies and economies..$^{5-7}$ In 2011, Cripps et al reported the global prevalence of SCI to be between 236 and 1,009 per million, a figure similar to that estimated by Blumer and Quine in 1995 (110-1,120 per million). ${ }^{5,7}$ Although several studies have attempted to quantify worldwide prevalence and incidences, several issues have prevented an accurate estimate. First, there is no standardized method of assessment across regions; second, the estimates for some countries have been extrapolated from numbers obtained in either urban or rural areas and therefore may not be entirely representative; third, a large proportion of global prevalence data is from developed nations such as Spain and the United States of America, with limited information from developing continents including Africa, South America, and Asia; and finally, given that there is such a high mortality rate at the scene of the accident and during patient retrieval and transport, many studies have underestimated figures.

This study aims to summarize the literature discussing incidence and prevalence of SCI and provide an up-to-date review of its epidemiology. This knowledge is necessary to quantify the rate of occurrence, track the efficacy of preventative measures, and provide estimates of the burden of SCI on the patient and the system.

\section{Methods}

A systematic search was conducted using PubMed, MEDLINE, MEDLINE in process, EMBASE, Cochrane Controlled Trial Register, and Cochrane Database of Systematic Reviews to identify relevant literature published through June 2013. Only studies on humans and those written in English were considered for this review. The keywords used for the search were SCI, causation, epidemiology, incidence, and prevalence. Case reports, meeting abstracts, and editorials were excluded.

All abstracts and titles were reviewed independently by two of the authors and were sorted based on predefined inclusion criteria. We sought studies that provided regional, provincial/state, or national data on the incidence of SCI or reported estimates of disease prevalence. The bibliographies of included articles were also systematically screened. From the prevalence studies, the following information was extracted: definition of acute SCI, how prevalence was calculated or estimated, and reported figures. From the included incidence articles, the following data were collected: definition of acute SCI, methodology of data collection, reported incidence, male:female ratio, age of peak incidence, causation, and level of injury.

The level of evidence of each study was evaluated using a scale developed for this review using guidelines from the Agency for Healthcare Research and Quality. This scale consisted of ten questions related to study design, sampling methodology, sampling bias, precision, and reliability of estimates. Further, two questions discussed whether the studies adequately defined SCI and whether patients who died at the site of injury were included in the incidence figure. The rating scale addresses all methodological components of epidemiology studies and was specifically developed to target SCI incidence and prevalence literature. Table 1 displays the rating scale as well as interpretations for each of the ten questions. 
Table I Quality rating scale for incidence and prevalence studies

\begin{tabular}{|c|c|}
\hline Checklist item original & Comments/interpretations \\
\hline $\begin{array}{l}\text { I. Was the primary objective of the study to estimate the incidence } \\
\text { or prevalence of SCI? }\end{array}$ & Minor flaw if target population was not well defined. \\
\hline $\begin{array}{l}\text { 2. What was the study design? } \\
\text { a. Cross-sectional } \\
\text { b. Retrospective } \\
\text { c. Prospective }\end{array}$ & Minor flaw if study design was retrospective. \\
\hline $\begin{array}{l}\text { 3. How was } \mathrm{SCl} \text { defined? } \\
\text { a. ICD codes } \\
\text { b. Standard clinical definition }\end{array}$ & $\begin{array}{l}\text { Minor flaw if definition was vague or did not include all relevant ICD codes. } \\
\text { Minor flaw if definition of SCl was not provided. }\end{array}$ \\
\hline $\begin{array}{l}\text { 4. Sampling methodology } \\
\text { a. Sampling subjects from the general population } \\
\text { b. Nongeneral population sampling methods } \\
\text { c. Nongeneral population-based sampling frame }\end{array}$ & $\begin{array}{l}\text { Minor flaws if random sampling was restricted to a specific geographic area (a). } \\
\text { Minor flaws if sampling methods were "convenient" or self-reported (b). } \\
\text { Minor flaws if sampling was based on medical records, insurance claims, } \\
\text { workplace, or health care-based (c). }\end{array}$ \\
\hline 5. Is there sampling bias? If so, was it addressed in the analysis? & $\begin{array}{l}\text { Minor flaw if there was sampling bias. } \\
\text { Minor flaw if sampling bias was not reduced in analysis. }\end{array}$ \\
\hline $\begin{array}{l}\text { 6. How was } \mathrm{SCl} \text { identified or confirmed in population of interest? } \\
\text { a. Self-reported } \\
\text { b. Proxy-reported } \\
\text { c. Objectively measured with diagnostic methods } \\
\text { d. Interviews } \\
\text { e. Obtained during clinical exam for the purpose of the study } \\
\text { f. Obtained from medical records or administrative databases } \\
\text { g. Obtained from registries }\end{array}$ & $\begin{array}{l}\text { Minor flaws if self-reported or if data was mined from medical records or } \\
\text { administrative databases. }\end{array}$ \\
\hline 7. Were patients who died at the site of injury included? & Minor flaw if incidence figures did not include these patients. \\
\hline 8. How was the incidence/prevalence reported? & Minor flaw if point prevalence was reported. \\
\hline 9. Is the precision of the estimate reported? & $\begin{array}{l}\text { Minor flaw if mean and variance of incidence or prevalence estimates were } \\
\text { not reported ( } 95 \% \text { confidence intervals or standard error). }\end{array}$ \\
\hline 10. Are the estimates reliable? & Minor flaw if reliability was not reported or if its evaluation was subjective. \\
\hline
\end{tabular}

Abbreviations: ICD, International Classification of Diseases; $\mathrm{SCl}$, spinal cord injury.

Based on rating distributions, a study was classified as high if it scored $\geq 8$ (two or fewer minor flaws), as medium if it scored between 5 and 7 , and low if it scored $<5$ points. The Table S1 provides a detailed overview of how each article was rated, and Tables 2 and 3 summarize whether each article was high, medium, or low-level evidence.

The bulk of this literature reported the incidence, prevalence, and primary causes of SCI as well as interesting demographic trends in this patient population. We did not exclude studies based on class of evidence, but rather included all relevant articles in an attempt to provide the most detailed review on the incidence and prevalence of SCI around the globe.

\section{Results}

The initial search yielded 5,874 citations. Forty-three studies met all inclusion criteria and discussed either the incidence or prevalence of SCI at a regional, state/provincial, or national level. An additional five studies were identified after systematically searching the bibliographies of included articles. Of these 48, 43 estimated the incidence of SCI and nine reported the prevalence, with five discussing both.
Figure 1 displays the detailed search strategy and review process.

\section{Prevalence}

Prevalence is the proportion of a population living with a disease at a particular time. In our review, nine studies reported the prevalence of acute SCI. Of these, four provided national rates and five estimated prevalence in city centers or counties. ${ }^{8-16}$ Various methodologies were used to achieve the closest approximation, including to 1) survey a portion of the population considered representative and, through interview, determine potential cases of SCI; 2) use the equation Prevalence $=$ ID, where I is the annual incidence and D is the duration of disease; and 3) review available registers at rehabilitation centers, long-term care centers, and surgical departments. Table 2 displays how each study defined acute SCI and calculated prevalence.

The prevalence of SCI in the United States of America has been estimated by three studies. In 1975, John Kurtzke reported a prevalence of 525 per million by multiplying the incidence of 30 per million by an average life duration of 18 years. ${ }^{17}$ Since the age of peak incidence is typically 
Table 2 Prevalence studies

\begin{tabular}{ll}
\hline Region/state/country & Definition of acute SCI \\
\hline $\begin{array}{l}\text { United States of America } \\
\text { (I988-1989) }\end{array}$ Not defined \\
Medium
\end{tabular}

\begin{tabular}{|c|c|}
\hline $\begin{array}{l}\text { Rhone-Alpes Region, France } \\
(1970-1975)^{14}\end{array}$ & Not defined \\
\hline \multicolumn{2}{|l|}{ Low } \\
\hline Iceland (1975-2009)"। & ICD-9 codes 806 and 952, and ICD-I0 \\
\hline \multirow[t]{4}{*}{ Medium } & codes S14, S24, and S34 since 1997. \\
\hline & Patients with isolated injuries of the nerve \\
\hline & roots and patients with symptoms lasting \\
\hline & for $<2$ weeks were excluded \\
\hline Western Norway $(1952-2001)^{13}$ & Clinical definition* \\
\hline \multicolumn{2}{|l|}{ Medium } \\
\hline Tehran, Iran (2007-2008) & Not defined \\
\hline Medium & \\
\hline
\end{tabular}

\begin{tabular}{ll} 
Prevalence calculation & Prevalence \\
\hline Mixed-model sampling design was used & 721 per million \\
to survey both noninstitutionalized and & \\
institutionalized populations. & \\
Noninstitutionalized: area segments were & \\
selected with primary sampling units. & \\
Institutionalized: nursing and long-term care \\
health facilities within primary sampling units \\
were sampled.
\end{tabular}

Calculated by multiplying annual incidence $\quad 906$ per million with life duration.

All Olmsted county residents with residual Point prevalence: neurologic deficits from SCl. Includes patients 220 per million in who had their injuries prior to 1935 as well as 1950 and 583 per those who moved to the county after injury. million in 1981 Subjects were identified from the following 280 per million sources: Kapyla Rehabilitation center,

Department of Orthopedic Surgery at Helsinki University Central Hospital, local organization of the disabled, local health centers, residential service houses and published announcements. Calculated by multiplying incidence by average life duration (Henry Gabrielle Hospital).

Prevalence was based on survival data on
$\mathrm{SCl}$ patients included in study as well as
$\mathrm{I} 0$ patients injured between 1973 and 1974 .

Number of patients with SCI/I00,000

inhabitants living in Hordaland and Sogn og

Fjordane counties on January I, 2002.

Two-stage survey strategy: detect all potential Point prevalence: cases in study population and then confirm $\quad 440$ per million that patients had SCl.

Calculated by dividing the number of definite alive $\mathrm{SCl}$ cases by the total number of the study population.

Calculated by multiplying current incidence by disease duration (Australian Spinal Cord Injury Register).

Australia (1986-1997) $\quad$ Not defined Notes: For ICD-9/10 codes, see Table S2. *Acute, traumatic lesion of the spinal cord resulting in motor and/or sensory deficit and/or bowel/bladder dysfunction, either temporary or permanent.

Abbreviations: ICD, International Classification of Disease; SCI, spinal cord injury.

between 15 and 30 years of age, patients with a disease duration of 18 years would only live to be between 33 and 48 years. Using life expectancy tables, DeVivo et al first re-estimated the average postinjury life span of a patient as 30.2 years and calculated prevalence as 906 per million. ${ }^{8}$ Finally, Harvey et al proposed a mixed-mode sampling method to identify SCI cases in both a noninstitutionalized and institutionalized setting. ${ }^{9}$ First, 120 representative primary sampling units were chosen and area segments within these locations were selected. Households were then surveyed to identify people living with SCI and to learn about cases within the neighborhood or family. Second, a sample of nursing and long-term health care facilities from the primary sampling units were chosen and screened for potential cases. The total prevalence was estimated to be 721 per million.

Other countries that have quantified prevalence at a national level are Australia and Iceland..$^{10,11}$ O'Connor used current incidence and survival data from the Australian Spinal Cord Injury Register and estimated a prevalence of 681 per million in $1997 .{ }^{10}$ In Iceland, the crude prevalence was 526 per million in 2009. ${ }^{11}$ 
Table 3 Incidence studies

\begin{tabular}{|c|c|c|c|}
\hline Author & Location & Definition of acute spinal cord injury & Data extraction \\
\hline \multicolumn{4}{|c|}{ States and provinces of the United States or Canada } \\
\hline Pickett et al $(2003)^{20}$ & Ontario, Canada & ICD-9 codes N-806 or $\mathrm{N}-952$ & Ontario Trauma Registry \\
\hline \multicolumn{4}{|l|}{ High } \\
\hline McCammon and & Manitoba, Canada & Survival to hospital admission with $\mathrm{SCl} /$ & Winnipeg Rehabilitation Hospital and the \\
\hline Ethans $(20 \mathrm{II})^{21}$ & & $\mathrm{NTSCl}$ or outpatient referral to a SCl & Manitoba branch of the Canadian Paraplegic \\
\hline Low & & rehabilitation specialist & Association \\
\hline Dryden et al $(2003)^{19}$ & Alberta, Canada & ICD-9 codes $806 . x$ or $952 . x$ & Alberta Health and Wellness databases, Alberta \\
\hline Medium & & Clinical definition* & $\begin{array}{l}\text { Trauma Registry, Office of the Chief Medical } \\
\text { Examiner }\end{array}$ \\
\hline Lenehan et al $(2012)^{18}$ & British Columbia, & ICD-9 codes 806.x and 952.x & Vancouver General Hospital \\
\hline \multirow[t]{2}{*}{ Medium } & Canada & & Provincial resources such as the British Columbia \\
\hline & & & Trauma Registry \\
\hline Price et al $(1994)^{22}$ & Oklahoma, USA & Clinical definition* & Multilevel surveillance system: physicians and \\
\hline Medium & & & hospitals reported acute injury, rehabilitation \\
\hline & & & centers reported postacute injury, and State Medical \\
\hline & & & Examiner reported fatal injury; $\mathrm{SCl}$ surveillance \\
\hline & & & systems in Texas and Colorado reported Oklahoma \\
\hline & & & residents injured in those states \\
\hline Surkin et al $(2000)^{25}$ & Mississippi, USA & ICD-9 codes $806.0-9$ and $952.0-9$ & The Mississippi SCl surveillance system \\
\hline \multirow[t]{2}{*}{ Medium } & & $\begin{array}{l}\text { Additionally, } 805.0-9 \text { were used to } \\
\text { identify potential cases }\end{array}$ & \\
\hline & & Clinical definition* & \\
\hline Thurman et al $(1994)^{24}$ & Utah, USA & ICD-9 codes $806.0-9$ and $952.0-9$ & Statewide reporting system of the Utah Department \\
\hline Medium & & Clinical definition* & $\begin{array}{l}\text { of Health, Bureau of Epidemiology (discharge data } \\
\text { from all acute care hospitals, list of patients with SCl } \\
\text { from rehabilitation units and death certificates) }\end{array}$ \\
\hline Warren et al $(1995)^{23}$ & Alaska, USA & ICD-9 codes $806.0-9$ and $952.0-953.99$ & Alaska Trauma Registry, National Center for \\
\hline Medium & & Clinical definition* & $\begin{array}{l}\text { Health Statistics, US Centers for Disease Control } \\
\text { and Prevention }\end{array}$ \\
\hline $\begin{array}{l}\text { Kraus et al }(1975)^{27} \\
\text { Medium }\end{array}$ & California, USA & $\begin{array}{l}\text { Acute, traumatic lesion of the spinal cord, } \\
\text { including trauma to the nerve roots, } \\
\text { resulting in varying degrees of motor/ } \\
\text { sensory deficit or paralysis }\end{array}$ & $\begin{array}{l}\text { All hospitals and coroner's offices in each county } \\
\text { and from the records of the State of California } \\
\text { Departments of Health, Rehabilitation, and } \\
\text { Industrial Relations }\end{array}$ \\
\hline $\begin{array}{l}\text { Fine et al }(1979-1980)^{26} \\
\text { Low }\end{array}$ & Alabama, USA & Not defined & $\begin{array}{l}\text { Model Regional SCI Center at the University of } \\
\text { Alabama }\end{array}$ \\
\hline \multicolumn{4}{|l|}{ Regions } \\
\hline Pickett et al $(2006)^{37}$ & London, Canada & ICD-9 codes 952.x and 806.x & London Health Sciences Center \\
\hline \multicolumn{4}{|l|}{ Medium } \\
\hline Burke et al $(200 \mathrm{I})^{32}$ & Counties in & ICD-9 codes $806.0-9$ and $952.0-9$ & University of Louisville Hospital SCI Trauma \\
\hline Medium & $\begin{array}{l}\text { Kentucky and } \\
\text { Indiana, USA }\end{array}$ & & Registry and patient records \\
\hline Griffin et al $(1985)^{15}$ & Olmsted County, & Definition coined by Kraus et $\mathrm{a}^{27}$ & Medical records-linkage system of the Rochester \\
\hline Medium & Minnesota & $\begin{array}{l}\text { Injuries extending from the foramen } \\
\text { magnum to the cauda equina and complete } \\
\text { nerve root avulsions were included }\end{array}$ & $\begin{array}{l}\text { Project at the Mayo Clinic } \\
\text { Death certificates and autopsy protocols }\end{array}$ \\
\hline $\begin{array}{l}\text { Minaire et al }(1978-1979)^{14} \\
\text { Low }\end{array}$ & $\begin{array}{l}\text { Rhone-Alpes } \\
\text { region, France }\end{array}$ & Not defined & Henry Gabrielle Hospital \\
\hline $\begin{array}{l}\text { Divanoglou and Levi }(2009)^{36} \\
\text { High }\end{array}$ & $\begin{array}{l}\text { Thessaloniki, } \\
\text { Greece and }\end{array}$ & $\begin{array}{l}\text { Acute traumatic injury of the spinal cord, } \\
\text { including cauda equina and conus medullaris }\end{array}$ & $\begin{array}{l}\text { Thessaloniki: four tertiary hospitals handling } \\
\text { acute } \mathrm{SCl}\end{array}$ \\
\hline & $\begin{array}{l}\text { Stockholm, } \\
\text { Sweden }\end{array}$ & $\begin{array}{l}\text { injuries, resulting in motor/sensory deficits } \\
\text { and/or bladder/bowel dysfunction persisting } \\
\text { for at least } 72 \text { hours post-trauma }\end{array}$ & $\begin{array}{l}\text { Stockholm: one hospital-based spinal injury unit, } \\
\text { two inpatient rehabilitation centers, and one } \\
\text { outpatient clinic for life-long follow-up }\end{array}$ \\
\hline Hagen et al $(2010)^{13}$ & Hordaland and & Clinical definition* & Eight hospitals within the two counties; data \\
\hline Medium & $\begin{array}{l}\text { Sogn og Fjordane, } \\
\text { Norway }\end{array}$ & & $\begin{array}{l}\text { collection was carried out according to a subset } \\
\text { of the Nordic SCl registry }\end{array}$ \\
\hline Martins et al $(1998)^{29}$ & Central region of & ICD-9 codes 806 and 952 & Coimbra Hospital Center and Coimbra University \\
\hline Medium & Portugal & Clinical definition* & $\begin{array}{l}\text { Hospitals; Department of Legal Medicine to } \\
\text { identify deaths resulting from trauma }\end{array}$ \\
\hline
\end{tabular}


Table 3 (Continued)

\begin{tabular}{|c|c|c|c|}
\hline Author & Location & Definition of acute spinal cord injury & Data extraction \\
\hline $\begin{array}{l}\text { Van den Berg et al }(20 \mathrm{II})^{33} \\
\text { Medium }\end{array}$ & Aragon, Spain & $\begin{array}{l}\text { ICD-9 codes } 806.0-9 \text { and } 952.0-9 \\
\text { Clinical definition* }\end{array}$ & $\begin{array}{l}\text { SCl unit of Servet Hospital; hospital archives and } \\
\text { central database in other units }\end{array}$ \\
\hline $\begin{array}{l}\text { Karamehmetoğlu }(1997)^{28} \\
\text { Low }\end{array}$ & Southeast, Turkey & Not defined & $\begin{array}{l}\text { Records obtained from emergency services, } \\
\text { ICUs, and departments of orthopedic surgery, } \\
\text { neurosurgery, and rehabilitation medicine }\end{array}$ \\
\hline $\begin{array}{l}\text { Rahimi-Movaghar et al (2009) } \\
\text { Medium }\end{array}$ & Tehran, Iran & Not defined & Primarily a prevalence study (not applicable) \\
\hline $\begin{array}{l}\text { Silberstein and Rabinovich } \\
(1995)^{35} \\
\text { Low }\end{array}$ & $\begin{array}{l}\text { Novosibirsk, } \\
\text { Russia }\end{array}$ & Not defined & $\begin{array}{l}\text { Department of Spinal Cord Injuries at the } \\
\text { Research Institute of Traumatology }\end{array}$ \\
\hline $\begin{array}{l}\text { Chen et al }(1985)^{34} \\
\text { Medium }\end{array}$ & Taipei, Taiwan & ICD-9 codes 806.0-9 and 968.0-9 & General Hospitals in the city of Taipei \\
\hline Lan et al $(1993)^{31}$ & Hualien County & Definition coined by Kraus et al (1975) & Buddhist Tz'u-Chi General, Provincial Hualien \\
\hline Medium & Taiwan & ICD-9 codes 806.0-9 and 968.0-9 & $\begin{array}{l}\text { Hospital, Mennonite Christian General Hospital, } \\
805 \text { Military Hospital }\end{array}$ \\
\hline Countries & & & \\
\hline $\begin{array}{l}\text { Bracken et al }(1981)^{38} \\
\text { Medium }\end{array}$ & USA & ICDA- 8 codes $344,805,806$, and 958 & $\begin{array}{l}\text { National Center for Health Statistics-Hospital } \\
\text { Discharge Survey }\end{array}$ \\
\hline $\begin{array}{l}\text { Biering-Sørensen et al }(1990)^{39} \\
\text { Low }\end{array}$ & Denmark & Spinal cord or cauda equina lesions & $\begin{array}{l}\text { Rehabilitation hospital in Hornbaek and special } \\
\text { rehabilitation hospital in Hald Ege }\end{array}$ \\
\hline $\begin{array}{l}\text { Sabre et al }(2012)^{40} \\
\text { Medium }\end{array}$ & Estonia & $\begin{array}{l}\text { ICD-I0 codes: G82, SI2.0-SI2.2, SI2.7, } \\
\text { SI3.0, SI3.2, SI3.4, SI4.0-I, S22.0, S23.0-I, } \\
\text { S24.0-I, S32.0, S33.0-I, S34.0-I, S34.3, } \\
\text { T06.0-I, T09.3, T9I.I, T9I.3 }\end{array}$ & $\begin{array}{l}\text { Northern Estonia Medical Centre and Tartu } \\
\text { University Hospital; all Estonian rehabilitation, } \\
\text { center, and general hospitals }\end{array}$ \\
\hline $\begin{array}{l}\text { Ahoniemi et al }(2008)^{41} \\
\text { Medium }\end{array}$ & Finland & $\begin{array}{l}\text { ICD-9 codes } 806,952 \text {, and } 9072 \text { A in } 1995 \text {; } \\
\text { ICD- } 10 \text { in } 1996 \text {, and SI4-S34 after }\end{array}$ & Käpylä Rehabilitation Center \\
\hline $\begin{array}{l}\text { Albert et al }(2005)^{42} \\
\text { Medium }\end{array}$ & France & $\begin{array}{l}\text { New traumatic spinal cord lesion, } \\
\text { paraplegia or tetraplegia, flaccid or spastic, } \\
\text { traumatic cauda equina syndrome }\end{array}$ & $\begin{array}{l}\text { Rehabilitation units, from both public and private } \\
\text { sectors }\end{array}$ \\
\hline $\begin{array}{l}\text { Pedersen et al (1989) } \\
\text { Low }\end{array}$ & Greenland & Not defined & $\begin{array}{l}\text { Rehabilitation center for } \mathrm{SCl} \text { in Hornbaek: } \\
\text { admitted after injury or transferred from the } \\
\text { Neurosurgical Department, Rigshopitalet } \\
\text { (University Hospital in Copenhagen) }\end{array}$ \\
\hline $\begin{array}{l}\text { Knútsdóttir et al }(2012)^{11} \\
\text { Medium }\end{array}$ & Iceland & $\begin{array}{l}\text { ICD-9 codes } 806 \text { and } 952 \text { until } 1997 \text { and } \\
\text { ICD- I } 0 \text { codes S14, S24, and S34 after I997; } \\
\text { patients with isolated injuries of nerve } \\
\text { roots and those diagnosed with a symptom } \\
\text { duration }<2 \text { weeks were excluded }\end{array}$ & Landspitali University Hospital in Iceland \\
\hline $\begin{array}{l}\text { O'Connor and Murray }(2006)^{44} \\
\text { Medium }\end{array}$ & Ireland & Not defined & National Rehabilitation Hospital \\
\hline $\begin{array}{l}\text { Van Asbeck et al }(2000)^{45} \\
\text { Medium }\end{array}$ & The Netherlands & ICD-9 codes 806 or 952 & National Registration for Disease \\
\hline $\begin{array}{l}\text { Gjone et al (1978-1979) } \\
\text { Low }\end{array}$ & Norway & Traumatic paraplegia and tetraplegia & Questionnaire sent out to 62 Norwegian hospitals \\
\hline $\begin{array}{l}\text { Soopramanien }(1994)^{47} \\
\text { Low }\end{array}$ & Romania & Not defined & Dr Gh Marinescu Hospital in Bucharest \\
\hline $\begin{array}{l}\text { Garcia-Reneses et al }(1991)^{56} \\
\text { Low }\end{array}$ & Spain & Not defined & Questionnaires were sent to 13 hospitals \\
\hline $\begin{array}{l}\text { Pérez et al }(2012)^{48} \\
\text { Medium }\end{array}$ & Spain & ICD-9 codes 806 and 952 & $\begin{array}{l}\text { National Hospital Discharge Register (Conjunto } \\
\text { Minimo Basico de Datos) }\end{array}$ \\
\hline $\begin{array}{l}\text { Gehrig et al (1960-1967) } \\
\text { Low }\end{array}$ & Switzerland & Acute paraplegia and tetraplegia & A letter was written to all hospitals in Switzerland \\
\hline $\begin{array}{l}\text { Karacan et al }(2000)^{50} \\
\text { Medium }\end{array}$ & Turkey & Not defined & $\begin{array}{l}\text { Study charts as questionnaires were sent to medical } \\
\text { institutes nationwide; records of SCI were obtained } \\
\text { from ICUs, emergency services, and orthopedic, } \\
\text { neurosurgery, and rehabilitation departments }\end{array}$ \\
\hline $\begin{array}{l}\text { Sabre et al }(2012)^{30} \\
\text { Medium }\end{array}$ & $\begin{array}{l}\text { Western Norway } \\
\text { and Estonia }\end{array}$ & $\begin{array}{l}\text { ICD- } 10 \text { codes suggesting SCl or fracture of } \\
\text { spinal column }\end{array}$ & $\begin{array}{l}\text { Medical records from } 8 \text { Norwegian and } \\
22 \text { Estonian Hospitals }\end{array}$ \\
\hline
\end{tabular}

(Continued) 
Table 3 (Continued)

\begin{tabular}{|c|c|c|c|}
\hline Author & Location & Definition of acute spinal cord injury & Data extraction \\
\hline Otom $(1997)^{51}$ & Jordan & Definition coined by Kraus et al (I975) & Royal Jordanian Rehabilitation Centre and King \\
\hline Medium & & & Hussein Medical Centre \\
\hline Shingu et al $(1994)^{52}$ & Japan & ICD-9 codes $806.0-9$ and $952.0-9$ & Questionnaire were sent to nationwide \\
\hline Low & & $\begin{array}{l}\text { Nerve root or plexus injuries were } \\
\text { excluded }\end{array}$ & $\begin{array}{l}\text { orthopedic and neurosurgery departments, } \\
\text { rehabilitation units, and emergency medical } \\
\text { service centers }\end{array}$ \\
\hline O'Connor $(2002)^{53}$ & Australia & Clinical definition* & Australian SCI Register \\
\hline \multicolumn{4}{|l|}{ Medium } \\
\hline Maharaj $(1996)^{55}$ & Fiji Islands & Spinal cord paralysis as defined by ASIA & Medical Rehabilitation Unit at Tamavua Hospital \\
\hline \multicolumn{4}{|l|}{ Low } \\
\hline $\begin{array}{l}\text { Dixon }(1993)^{54} \\
\text { Medium }\end{array}$ & New Zealand & $\begin{array}{l}\text { ICD- } 9 \text { codes: } 806,952 \text { and } 907.2,342,344 \text {, } \\
805,839 \text {, and } 953\end{array}$ & Health Statistics Services files of New Zealand \\
\hline
\end{tabular}

Notes: For ICD-8/9/10 codes, Table S2. *Acute, traumatic lesion of the spinal cord resulting in motor and/or sensory deficit and/or bowel/bladder dysfunction, either temporary or permanent.

Abbreviations: ASIA, American Spinal Injury Association score; ICU, intensive care unit; ICD, International Classification of Disease; NTSCI, nontraumatic SCI; SCI, spinal cord injury.

In Europe, prevalence has been estimated in Helsinki, Finland, Western Norway, and the Rhone-Alpes region in France. ${ }^{12-14}$ Patients with SCI living in Helsinki were identified using several sources: a list of in- or outpatients from the Kapyla Rehabilitation Center; ICD-9 or ICD-10 codes from the department of Orthopedic Surgery at Helsinki University Central Hospital; the membership of the local organization for the disabled; local health centers; residential service houses; and published announcements. ${ }^{12}$ With this information, the prevalence of SCI was reported to be 280 per million. In Western Norway, Hagen et al reviewed the records from eight hospitals within two Norwegian counties, Hordaland and Sogn og Fjordane. ${ }^{13}$ As of January 2002, the crude prevalence in this region was 365 per million, with rates of 351 per million and 419 per million in Hordaland and Sogn og Fjordane County, respectively. Finally, in the
Rhone-Alpes region, the prevalence was extrapolated from the incidence using an average duration of life of 20 years and was 250 per million. ${ }^{14}$

The true prevalence of Olmsted County, Minnesota was calculated by counting all SCI patients with residual neurological deficits living in this region in 1950, 1960, 1970, and $1980 .{ }^{15}$ This estimation also includes patients who moved to the county after sustaining an injury elsewhere. The point prevalence increased over time from 220.1 per million in 1950, 242.7 per million in 1960 , and 456.7 per million in 1970 to 582.5 per million in 1980 .

In Tehran, Iran, a two-stage survey strategy was used to evaluate the point prevalence of SCI. ${ }^{16}$ The study population was determined using random cluster sampling: 100 addresses were used as the starting point and 25 households around the same region were surveyed. If a potential case of SCI was

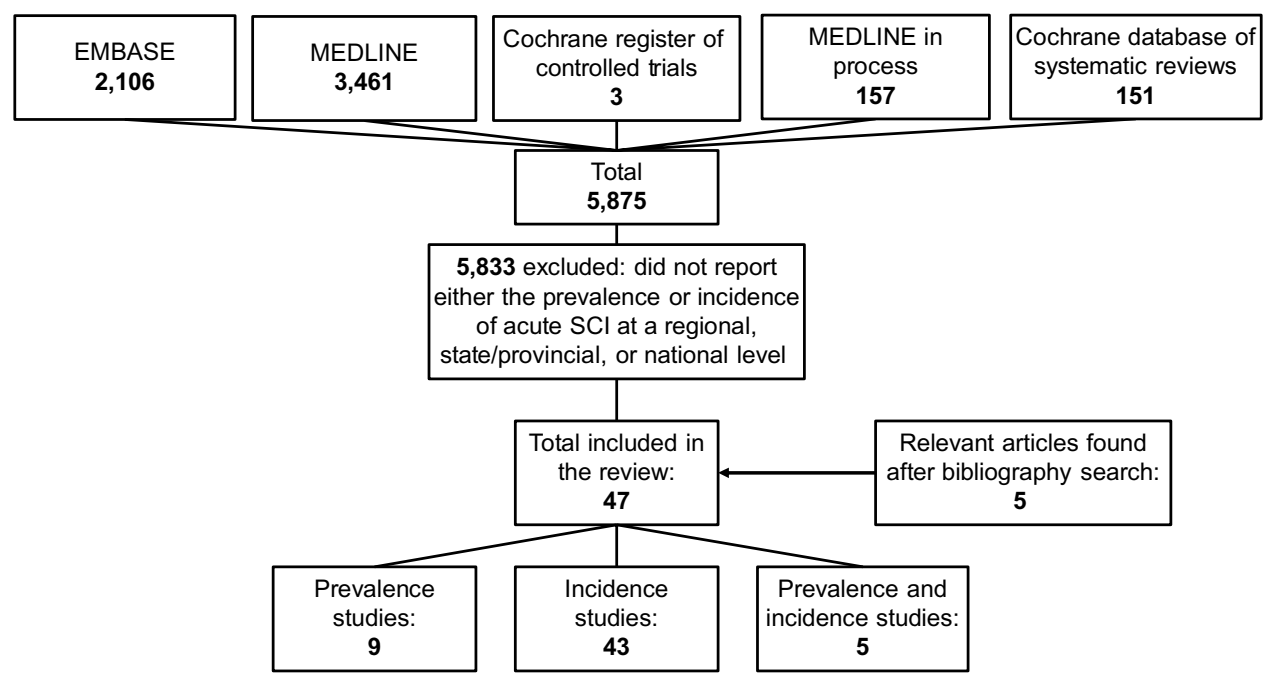

Figure I Detailed search and review strategy. Abbreviation: $\mathrm{SCl}$, spinal cord injury. 
detected, a nurse would go to the house and conduct a thorough examination to confirm the presence of a SCI. Point prevalence was defined as the number of alive SCI patients divided by the total number of the study population. It was 440 per million.

\section{Incidence}

The incidence of a disease is the number of new cases in a population at risk in a given time period. In this review, 44 studies reported on the incidence of SCI: 13 at a regional level, ten at a state or provincial level, and 21 at a national level. Figure 2 is a map of the world and highlights relative incidences. Figure 3 illustrates the incidence in countries, states/provinces, and regions of North America. Figure 4 displays the incidence in countries and regions of Asia Pacific (East Asia and Australia). Figure 5 presents the incidence in countries and regions of Europe and the Middle East. The majority of studies reported crude incidence, and therefore comparisons between countries, states/provinces, and regions could not be made.

\section{Provincial/state}

Ten studies assessed the incidence of SCI in North American states and provinces, including British Columbia, Alberta, Manitoba, and Ontario in Canada and Oklahoma, Mississippi, Utah, Alaska, Alabama, and California in the United States. ${ }^{18-27}$ Table 3 displays how each study defined acute SCI and the resources or systems used to estimate incidence. In 1975, Kraus et al defined SCI as an acute, traumatic lesion of the spinal cord, including trauma to the nerve roots, resulting in varying degrees of motor and/or sensory deficit or paralysis. ${ }^{27}$ Five studies used a slightly modified definition proposed by the Center for Disease Control and Prevention: an acute, traumatic lesion of neural elements in the spinal canal (spinal cord or cauda equina) resulting in motor and/or sensory deficit or bowel/bladder dysfunction, either temporary or permanent. ${ }^{19,22-25}$ In addition to the clinical definition, the majority of studies used ICD-9 codes to identify cases of acute SCI. ${ }^{18-20,23-25}$ Specifically, codes 806 (fracture of vertebral column with spinal cord lesion), 952 (spinal cord lesion without evidence of spinal bone injury), and 805 (fracture of the vertebral column without mention of spinal cord lesion) were deemed relevant. A detailed list of ICD codes is provided in Table $\mathrm{S} 2$.

In Canada, various resources were used to identify cases of SCI and to quantify an annual incidence. In Ontario, the Ontario Trauma Registry contains records for all acute care injury hospitalizations in the province and was searched for relevant diagnostic codes ${ }^{20}$ Similarly, Alberta has a trauma registry that provides detailed information on patient demographics, severity of injury, and causation. ${ }^{19}$ Two additional sources were used in Alberta: 1) the Health and Wellness database, which contains records of all hospitals and medical services in the province, and 2) the Office of the Chief Medical examiner, which investigates all unexplained deaths. To estimate incidence in British Columbia, only registers at the Vancouver General Hospital were reviewed, as this center represents the sole subspecialty SCI center in the province. ${ }^{18}$ Finally, in Manitoba, data from the Canadian Paraplegic Association and the Winnipeg Rehabilitation center were used to identify cases. ${ }^{21}$

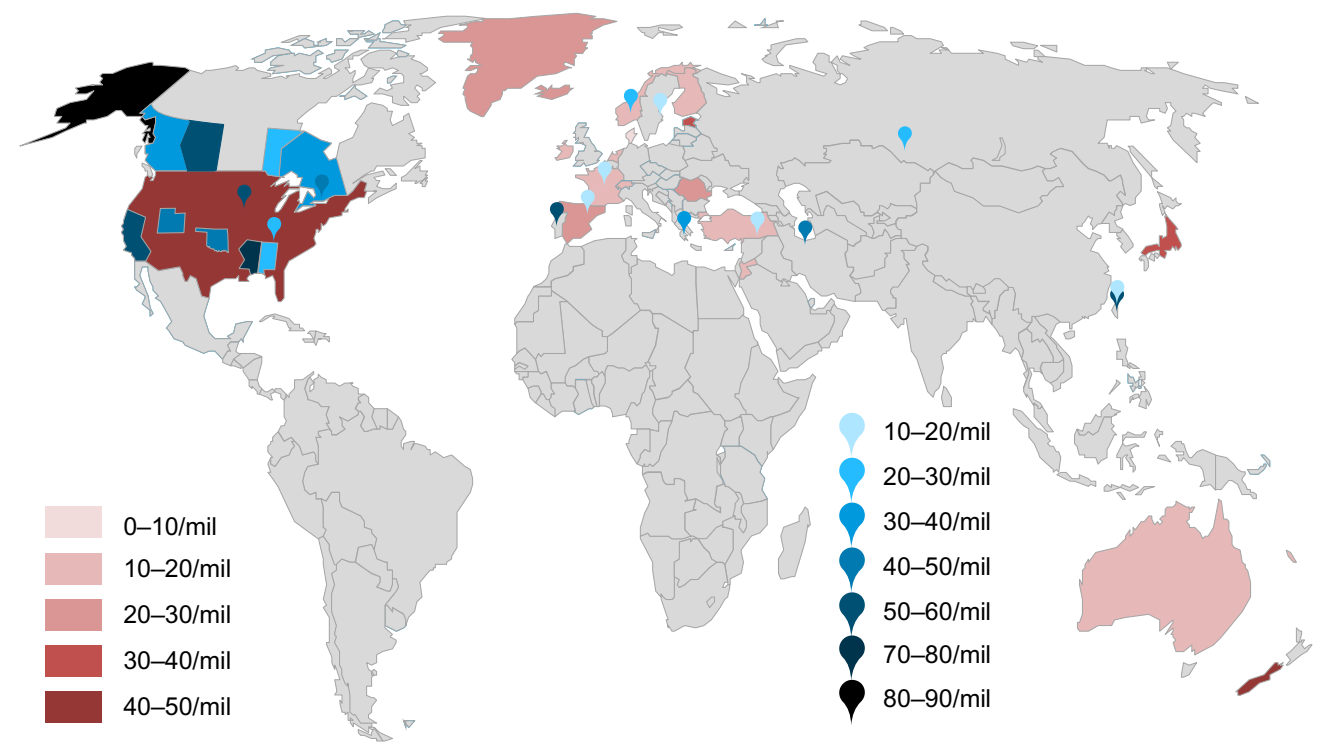

Figure 2 Relative annual incidences of countries, states/provinces, and regions.

Notes: The red color scheme illustrates incidences of countries. The blue color scheme highlights incidences of states/provinces and regions. Abbreviation: mil, million. 


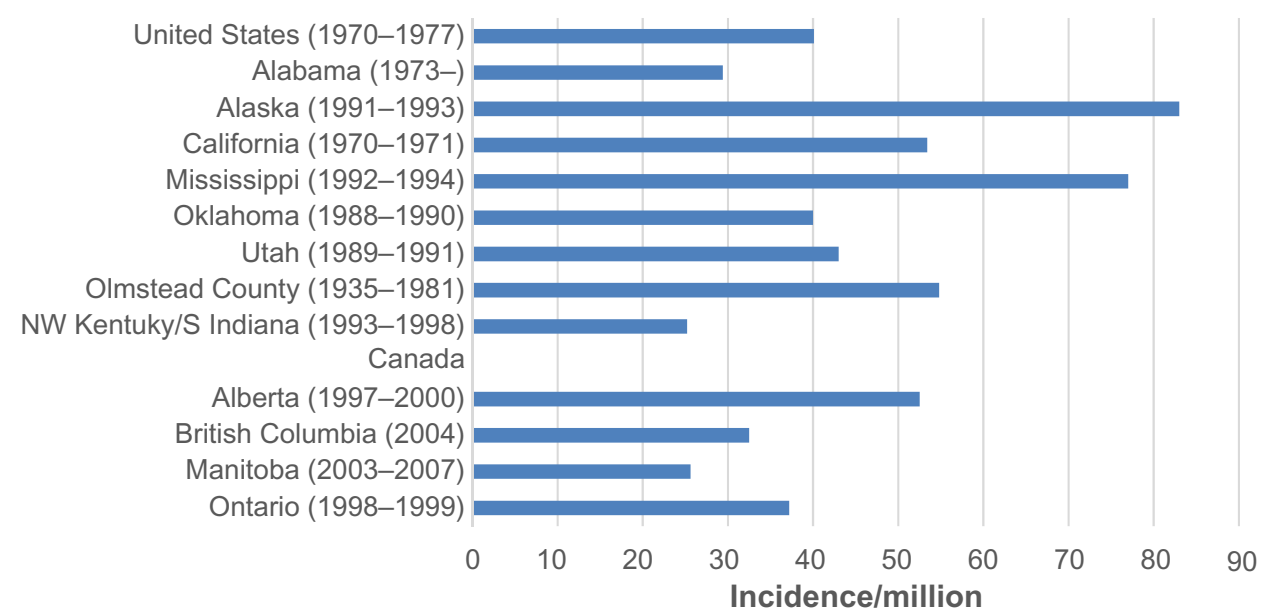

Figure 3 Annual incidence of spinal cord injury in regions within the United States of America and Canada, including provinces and states. Abbreviations: NW, Northwest; S, Southern.

Many studies in the United States used extensive surveillance systems to accurately identify all cases of SCI. For example, in Oklahoma and Utah, information was obtained from acute care centers, rehabilitation units and either the state medical examiner or death certificates. ${ }^{22,24}$ In addition, SCI surveillance systems in Texas and Colorado were used to detect Oklahoma residents who were injured in neighboring locations..$^{22}$ Kraus et al also used several resources including all hospitals and coroners in 18 Californian counties to identify all admitted SCI patients as well as those who died at the scene of the accident or during transfer. ${ }^{27}$ In contrast, the study by Warren et al used the Alaska Trauma Registry and the National Center for Health Statistics to determine national rates. ${ }^{23}$

Table 4 displays the annual incidence of SCI per million, the male-to-female ratio, age of peak incidence, causation, and level of injury in Canada and the United States of America. Incidences across provinces cannot be compared, as the data were collected at varying time points; however, exploring relative changes is valuable. In Alberta and Ontario, the incidence of SCI has decreased over time. ${ }^{19,20}$ In Ontario, the agestandardized incidence was 46.2 per million in 1994/1995 (95\% confidence interval [CI]: 42.1-50.3) and was 37.2 per million in 1998/1999 (95\% CI: 33.8-41.0). ${ }^{20}$ Over a 3-year period, the estimated incidence in Alberta decreased from 57 per million in 1997-1998 to 47.9 per million in 1999-2000. ${ }^{19}$ In British Columbia, there was a downward trend from 42.2 per million in 1995 to 32.5 per million in 2004, although the lowest rate was 27.9 per million in $1999 .{ }^{18}$ In contrast, the incidence progressively increased in Manitoba from 17.1 per million per year between 1981 and 1985 to 25.6 per million per year between 2003 and $2007 .{ }^{21}$ The five studies conducted

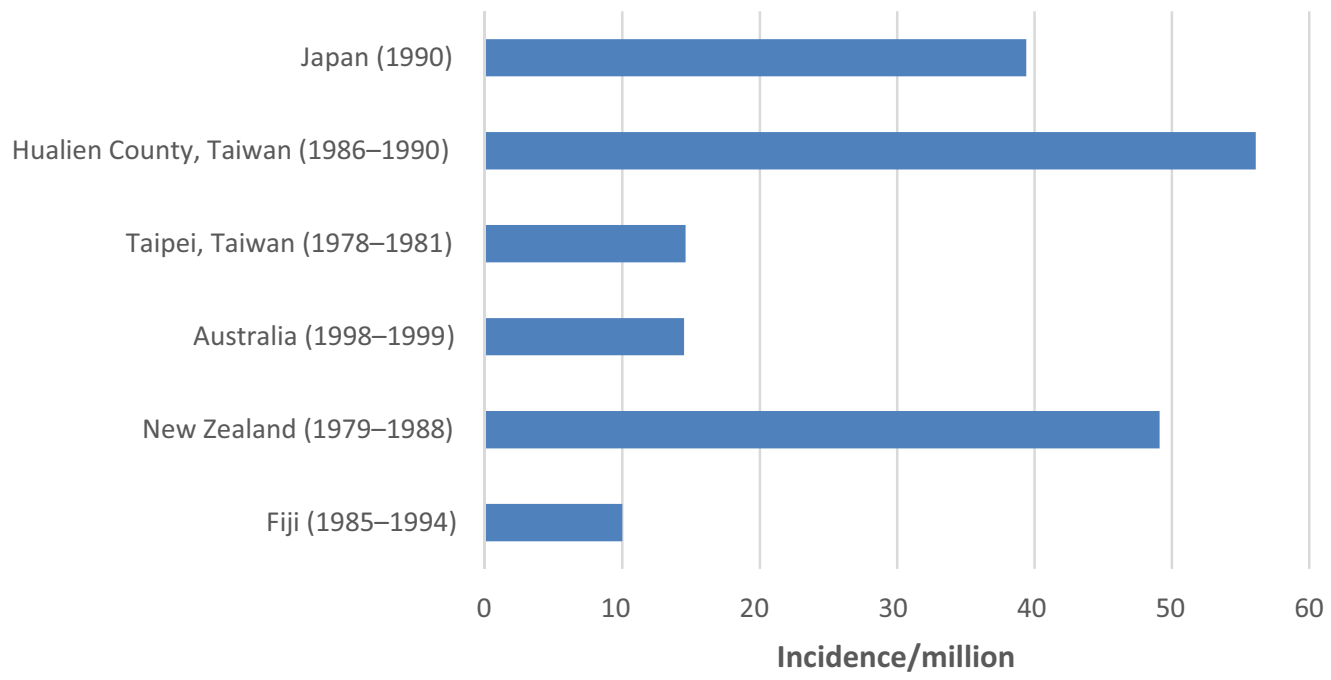

Figure 4 Annual incidence of spinal cord injury in regions and countries in Asia Pacific. 


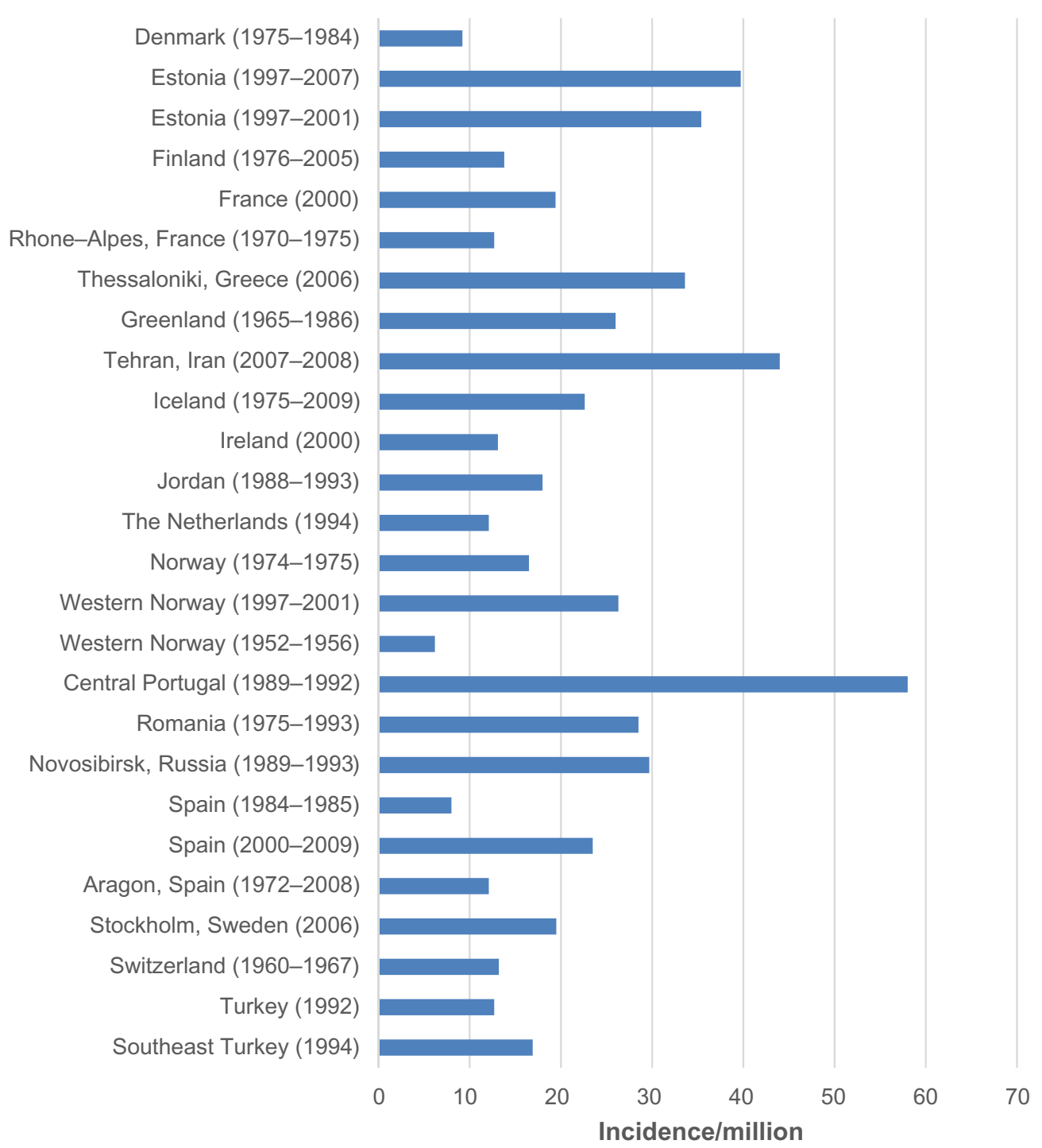

Figure 5 Annual incidence of spinal cord injury in regions and countries in Europe and the Middle East.

in the United States did not present a summary of incidence over time. Within 5 years, the incidence of Oklahoma, Alaska, Utah, and Mississippi were estimated. ${ }^{22-25}$ Alaska and Mississippi had much higher reported incidences of 83 per million and 77 per million, respectively, compared to incidence in Oklahoma (40 per million) and Utah (43 per million).

All studies showed a greater percentage of males with injuries compared to females. In Manitoba, however, the male-to-female ratio significantly decreased from the 1980 s $(12: 1)$ to the 2000 s $(4.4: 1)$ due to an increase in motor-vehicle-related injuries in females. ${ }^{21}$ The ratio in Alaska was 5:1, which was larger than any other state or province. ${ }^{23}$ As expected, the age of peak incidence was typically between 15 and 30 years of age. The age of peak incidence, however, was over 70 years of age for both males and females in Ontario and over 85 years of age for females in British Columbia. ${ }^{18,20}$ In Alberta, Oklahoma, and Alaska, the peak age of females was slightly younger than that of males. ${ }^{19,22,23}$

With respect to the etiology of SCI, studies used different definitions of traffic accidents, falls, violence, and sports. For example, motor vehicle accidents in British Columbia included all passengers, drivers, pedestrians, and cyclists injured during the accident. ${ }^{18}$ On the other hand, in Ontario, a traffic incident was divided into motor vehicle (occupant, motorcyclist, pedestrian, and pedal cyclist), nonmotorized vehicle (pedal cyclist, rider of animal and pedestrian), and air, space, and water transport. ${ }^{20}$ With a view to standardizing etiological definitions, we combined various causations into single categories: 1) all car, plane, motorcycle, and 
Table 4 Incidence and causation of spinal cord injury in provinces and states of Canada and the United States of America

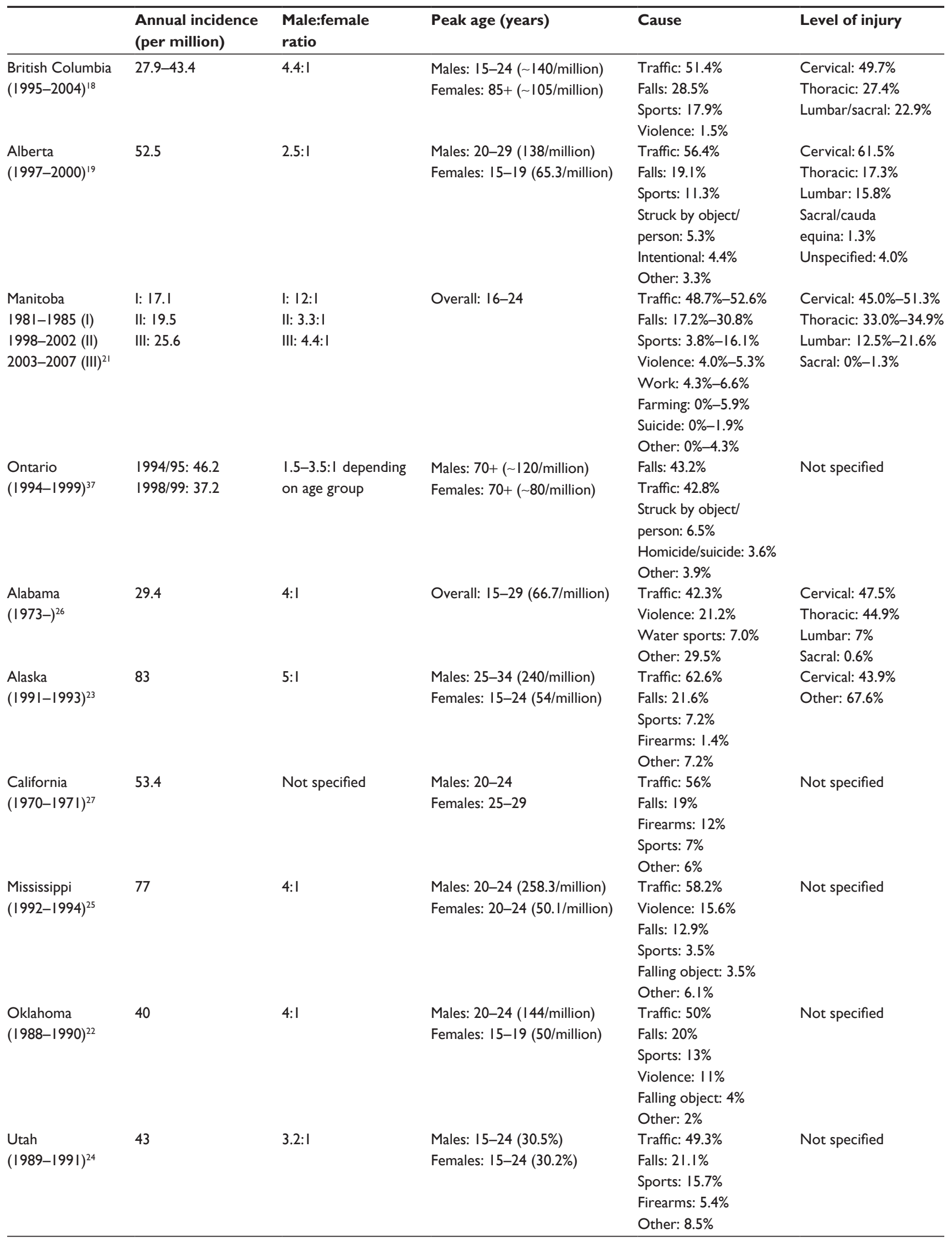


other transport accidents, including pedestrians and cyclists involved in collision, were defined as "traffic"; stabbing, gunshots, and assault were categorized as "violence"; all sport and recreation injuries, including diving, were considered "sports"; and intentional falls or self-inflicted injury were defined as "suicide."

Traffic accidents $(42.3 \%-62.6 \%)$ were the primary cause of SCI in all province and states, with the exception of Ontario, where falls were more prevalent. Falls, from either elevation or at ground level, were typically the second most common etiology. In Alabama and Mississippi, however, injuries due to violence made up a larger percentage $(21.2 \%$ and $15.6 \%$, respectively) than injuries due to falls. ${ }^{25,26}$ Only 1.5 to $5.3 \%$ of injuries in Canadian provinces were due to violence, a percentage significantly lower than in American states. ${ }^{18,21,22,25,26}$ Injuries due to sports and recreation, including diving, were the highest in British Columbia (17.9\%) and Utah (15.7\%) and the lowest in Mississippi (3.5\%). ${ }^{18,24,25}$ Suicide-related SCIs were not reported everywhere, making it difficult to draw conclusions on differences in rates.

The most common anatomical region of injury was the cervical spine $(43.9 \%-61.5 \%)$.

\section{Regions}

Nine studies reported on the incidence of various regions or counties, including Southeast Turkey; the central region of Portugal; Western Norway $(n=2)$; the Rhone-Alpes region in France; Aragon, Spain; Hualien County, Taiwan; Northwest Kentucky and Southern Indiana; and Olmsted county in Minnesota. ${ }^{13-15,28-32}$ An additional five studies estimated the incidence of SCI in cities: Tehran, Iran; Taipei, Taiwan; Novosibirsk, Russia; London, Canada; Stockholm, Sweden; and Thessaloniki, Greece. ${ }^{16,33-37}$

Table 3 illustrates how each study defined SCI and the sources used to obtain estimates of incidence. Studies by Griffin et al and Lan et al used the definition coined by Kraus et $\mathrm{al}^{27}$ and included patients with trauma to the nerve roots. ${ }^{15,31}$ Many other studies used the modified definition presented earlier and excluded patients with nerve root avulsions. ${ }^{13,29,33}$ In the study on Stockholm and Thessaloniki, SCI was defined as an acute traumatic injury of the spinal cord, including cauda equina and conus medullaris injuries, resulting in motor/sensory deficits and/or bladder/bowel dysfunction persisting for at least 72 hours post-trauma. ${ }^{36}$ This 72-hour requirement was not specified in previous definitions and likely excludes all patients who died at the scene of the accident or during transfer to an acute care center. The majority of studies also used ICD-9 codes to identify patients diagnosed with SCI: 806 and 952 as well as 968 (spinal cord lesion without evidence of spine injury) in Taiwanese regions or cities. . $^{29,31-34,37}$

The majority of studies used information from acute care centers and regional general hospitals to identify patients. This methodology was deemed adequate as many cities or regions only have a few centers that are responsible for managing patients with SCI. For example, the University of Louisville Hospital services people located within a 50-mile radius, including 18 counties in Kentucky and eleven counties in Indiana. ${ }^{32}$ In the study by Burke et al, ${ }^{32}$ incidence was calculated using information from the hospital's trauma registry and the US Census Bureau population estimates. Similarly, in the central region of Portugal, all acute SCIs are treated at the Coimbra hospitals; data extraction from these hospitals should therefore provide an accurate estimate of incidence. ${ }^{29}$ In addition, the department of Legal Medicine was accessed to identify patients who died from traumatic causes. In the Rhone-Alpes region and Western Norway, patients who had died prior to hospital arrival were not included. ${ }^{13,14}$ Although not specified, this was probably the case in many of the other studies included in this review.

Table 5 displays the annual incidence of SCI per million, the male-to-female ratio, age at peak incidence, causation, and level of injury for these regions. Again, these studies were conducted in different years and over varying lengths of time, making it challenging to compare estimates. The incidence of SCI significantly increased over time in Hordaland and Sogn og Fjordane County in Western Norway (6.2 per million in 1952-1956 to 26.3 per million in 1997-2001), Olmsted County in Minnesota (22.2 per million in 1935-1944 to 70.8 per million in 1975-1981), and in London, Ontario (21 per million in 1997 to 49 per million in 2000). ${ }^{13,15,37}$ There has also been a progressive increase in the number of SCI cases in the central region of Portugal, from 68 new cases in 1989 to 106 in 1992, likely reflecting an increase in incidence. ${ }^{29}$ In Aragon, Spain, following an increase from 8.2 per million in $1972-1980$ to 13.8 per million in 1981-1990, the incidence was relatively stable over the next 18 years. ${ }^{33}$ In the Rhone-Alpes region in France, there was no upward or downward trend in the number of SCI cases between 1970 and 1975, although an actual incidence was not given for each of these 6 years. ${ }^{14}$

Within similar time periods, the incidence of SCI in the central region of Portugal (58 per million) was similar to that in Hualien County, Taiwan (56.1 per million). ${ }^{29,31}$ Ten years earlier, the incidence of SCI in Taipei, Taiwan (14.6 per million) was significantly lower. ${ }^{31,34}$ Some possible 
Table 5 Incidence and causation of spinal cord injury in cities and regions

\begin{tabular}{|c|c|c|c|c|c|}
\hline & $\begin{array}{l}\text { Annual incidence } \\
\text { (per million } \\
\text { population) }\end{array}$ & Male:female ratio & Peak age & Causation & Level of injury \\
\hline $\begin{array}{l}\text { London, Ontario, } \\
\text { Canada }(1997-2000)^{20}\end{array}$ & $\sim 49$ in 2000 & $3: 1$ & Overall: $20-29(20 \%)$ & $\begin{array}{l}\text { Traffic: } 47 \% \\
\text { Falls: } 31 \% \\
\text { Sports: } 9.3 \% \\
\text { Work: } 6.6 \% \\
\text { Violence: } 4.6 \% \\
\text { Suicide: } 1.3 \%\end{array}$ & $\begin{array}{l}\text { Cervical: } 75 \% \\
\text { Thoracic: } 10 \% \\
\text { Lumbar: } 9 \% \\
\text { Junctions: } 6 \%\end{array}$ \\
\hline $\begin{array}{l}\text { Central Portugal region } \\
(1989-1992)^{29}\end{array}$ & 58 & $3.4: 1$ & $\begin{array}{l}\text { Males: 70-74 (285/million) } \\
\text { Females: 80-84 (64/million) }\end{array}$ & $\begin{array}{l}\text { Traffic: } 57.3 \% \\
\text { Falls: } 37.4 \% \\
\text { Other: } 5.3 \%\end{array}$ & $\begin{array}{l}\text { Cervical: } 51.2 \% \\
\text { Thoracic: } 41 \% \\
\text { Lumbar: } 7.8 \%\end{array}$ \\
\hline $\begin{array}{l}\text { Hualien county, Taiwan } \\
(1986-1990)^{31}\end{array}$ & 56.1 & $4: 1$ & $\begin{array}{l}\text { Overall: } 20-29 \text { and } 30-39 \\
\text { (19.2\% each group) }\end{array}$ & $\begin{array}{l}\text { Traffic: } 61.6 \% \\
\text { Falls: } 23.3 \% \\
\text { Sports: } 6.1 \% \\
\text { Struck by object: } 4 \% \\
\text { Violence: } 3 \% \\
\text { Suicide: } 2 \%\end{array}$ & Not specified \\
\hline $\begin{array}{l}\text { Taipei, Taiwan } \\
(1978-1981)^{34}\end{array}$ & 14.6 & 4.9:1 & Overall: $20-29$ (31.8\%) & $\begin{array}{l}\text { Traffic: } 44.5 \% \\
\text { Falls: } 28.5 \% \\
\text { Struck by object: } 14.6 \% \\
\text { Sports: } 3.4 \% \\
\text { Violence: } 2.7 \% \\
\text { Suicide: } 1.4 \% \\
\text { Other: } 5.6 \%\end{array}$ & $\begin{array}{l}\text { Cervical: } 46.8 \% \\
\text { Thoracic or } \\
\text { below: } 53.2 \%\end{array}$ \\
\hline $\begin{array}{l}\text { Novosibirsk, Russia } \\
(1989-1993)^{35}\end{array}$ & 29.7 & $3.6: 1$ & Overall: $20-29$ (38.3\%) & $\begin{array}{l}\text { Falls: } 37.3 \% \\
\text { Sports: } 32.9 \% \\
\text { Traffic: } 25.1 \% \\
\text { Suicide: } 3.1 \% \\
\text { Violence: } 1.6 \%\end{array}$ & $\begin{array}{l}\text { Cervical: } 49.0 \% \\
\text { Thoracic: } 27.5 \% \\
\text { Lumbar: } 23.5 \%\end{array}$ \\
\hline $\begin{array}{l}\text { Rhone-Alpes Region, } \\
\text { France }(1970-1975)^{14}\end{array}$ & 12.7 & $3.7: 1$ & Overall: $20-30$ & $\begin{array}{l}\text { Traffic: } 47.2 \% \\
\text { Falls: } 24.25 \% \\
\text { Sports: } 7.8 \% \\
\text { Struck by object: } 7.5 \% \\
\text { Suicide: } 4.3 \% \\
\text { Violence: } 0.8 \% \\
\text { Other: } 8.1 \%\end{array}$ & $\begin{array}{l}\text { Only specified by } \\
\text { causation }\end{array}$ \\
\hline $\begin{array}{l}\text { Northwestern Kentucky } \\
\text { and Southern Indiana } \\
(\text { (993-1998) })^{32}\end{array}$ & 25.2 & $3: 1$ & Overall: 18-24 (78.3/million) & $\begin{array}{l}\text { Traffic: } 54.7 \% \\
\text { Falls: } 23.0 \% \\
\text { Violence: } 14.2 \% \\
\text { Other: } 8.1 \%\end{array}$ & $\begin{array}{l}\text { Cervical: } 49.7 \% \\
\text { Thoracic: } 35.3 \% \\
\text { Lumbar: } 15.0 \%\end{array}$ \\
\hline $\begin{array}{l}\text { Olmstead County, } \\
\text { Minnesota }(1935-1981)^{15}\end{array}$ & 54.8 & $2.6: 1$ & Not given & Not given & Not given \\
\hline $\begin{array}{l}\text { Aragon, Spain } \\
(1972-2008)^{33}\end{array}$ & 12.1 & $3.9: 1$ & $\begin{array}{l}\text { Males: 20-29 (36.1/million) } \\
\text { Females: } 20-29(6.7 / \text { million })\end{array}$ & $\begin{array}{l}\text { Traffic: } 57.0 \% \\
\text { Falls: } 24.6 \% \\
\text { Violence: } 3.9 \% \\
\text { Sports: } 1.9 \%\end{array}$ & $\begin{array}{l}\text { Cervical: } 36.9 \% \\
\text { Thoracic: } 37.4 \% \\
\text { Lumbar: } 19.3 \% \\
\text { Sacral: } 4.3 \%\end{array}$ \\
\hline $\begin{array}{l}\text { Southeast, Turkey } \\
(1994)^{28}\end{array}$ & 16.9 & $5.8: 1$ & Overall: $40-49$ (52.6/million) & $\begin{array}{l}\text { Falls/traffic/violence: } 93.2 \% \\
\text { Struck by object: } 5.2 \% \\
\text { Suicide: } 1.3 \%\end{array}$ & Not reported \\
\hline $\begin{array}{l}\text { Thessaloniki, Greece } \\
(2006)^{36}\end{array}$ & 33.6 & $7: 1$ & Overall: 16-30 (4I\%) & $\begin{array}{l}\text { Traffic: } 51 \% \\
\text { Falls: } 37 \% \\
\text { Sports: } 4 \% \\
\text { latrogenic: } 4 \% \\
\text { Violence: } 2 \% \\
\text { Other: } 2 \%\end{array}$ & $\begin{array}{l}\text { Cervical: } 48 \% \\
\text { Thoracic: } 40 \% \\
\text { Lumbar/sacral: } 12 \%\end{array}$ \\
\hline
\end{tabular}

(Continued) 
Table 5 (Continued)

\begin{tabular}{|c|c|c|c|c|c|}
\hline & $\begin{array}{l}\text { Annual incidence } \\
\text { (per million } \\
\text { population) }\end{array}$ & Male:female ratio & Peak age & Causation & Level of injury \\
\hline $\begin{array}{l}\text { Stockholm, Sweden } \\
(2006)^{36}\end{array}$ & 19.5 & $3: 1$ & Overall: 6I-75 (28\%) & $\begin{array}{l}\text { Falls: } 47 \% \\
\text { Traffic: } 23 \% \\
\text { Sports: } 17 \% \\
\text { latrogenic: } 4 \% \\
\text { Violence: } 2 \% \\
\text { Other: } 6 \%\end{array}$ & $\begin{array}{l}\text { Cervical: } 43 \% \\
\text { Thoracic: } 45 \% \\
\text { Lumbar/sacral: I I\% }\end{array}$ \\
\hline $\begin{array}{l}\text { Western Norway } \\
(1997-2001)^{13}\end{array}$ & 26.3 & $3.4: 1$ & $\begin{array}{l}\text { Males: } 70-79(\sim 130 / \text { million }) \\
\text { Females: } 20-29 \\
(\sim 117 / \text { million })\end{array}$ & $\begin{array}{l}\text { Falls: } 45.1 \% \\
\text { Traffic: } 40.8 \% \\
\text { Sports: } 9.9 \% \\
\text { Other: } 4.2 \%\end{array}$ & $\begin{array}{l}\text { Cervical: } 57.8 \% \\
\text { Thoracic: } 21.1 \% \\
\text { Lumbar: } 21.1 \%\end{array}$ \\
\hline $\begin{array}{l}\text { Western Norway } \\
(1952-2001)^{30}\end{array}$ & $\begin{array}{l}6.2(1952-1956) \\
26.3(1997-2001)\end{array}$ & $4.7: 1$ & $\begin{array}{l}\text { Males: } 20-29 \\
\text { Females: 70-79 }\end{array}$ & $\begin{array}{l}\text { Falls: } 45.5 \% \\
\text { Traffic: } 34.2 \% \\
\text { Sports: } 8.6 \% \\
\text { Other: } 11.6 \%\end{array}$ & $\begin{array}{l}\text { Cervical: } 52.4 \% \\
\text { Thoracic: } 29.5 \% \\
\text { Lumbar/sacral: } \\
18.2 \%\end{array}$ \\
\hline $\begin{array}{l}\text { Tehran, Iran } \\
(2007-2008)^{16}\end{array}$ & 44 & Not specified & Not specified & Not specified & Not specified \\
\hline
\end{tabular}

explanations for this higher incidence in Hualien County are 1) motorcycles are the major transportation vehicle; 2 ) the Hualien region is a mountainous area with large mining and quarrying industries, resulting in an increased frequency of falls; and 3) alcoholism is much more common in rural regions of Taiwan than in urban city centers. ${ }^{31}$ The incidence of SCI in Taipei was similar to that in the Rhone-Alpes region of France (12.7 per million), Aragon, Spain (12.1 per million), and Southeast Turkey (16.9 per million). ${ }^{14,28,33,34}$

In a study by Divanoglou et al, the incidence of SCI was compared between Stockholm, Sweden and Thessaloniki, Greece. ${ }^{36}$ The annual crude incidence was 33.6 per million in Thessaloniki and was significantly higher than the incidence in Stockholm, Sweden (19.5 per million). The major difference between the two cities is that individuals from Thessaloniki were more frequently involved in transportation accidents, suggesting a need for improved road safety in Greece.

In all studies, there was a greater percentage of males with SCI than females. Eighty-eight percent of patients in Thessaloniki, Greece were male, representing the largest male:female ratio $(7: 1){ }^{36}$ The smallest ratio was $2.6: 1$ in Olmsted County, Minnesota. ${ }^{15}$ As expected, the age of peak incidence was typically between 15-30 years of age or over 70 years for both sexes. An exception to this was Southeast Turkey, where the peak incidence occurred in the 40-49 age group. ${ }^{28}$

With respect to the etiology of injury, traffic accidents were the primary cause of SCI in all regions (44.5\%-61.6\%), except for Novosibirsk, Russia (25.1\%), Stockholm, Sweden
(23\%), and Western Norway (34.2\%-40.8\%), where falls were more prevalent. Falls, either from elevation or ground level, were typically the second most common cause of SCI. In Novosibirsk, Russia and Stockholm, Sweden, 32.9\% and $17 \%$ of injuries were due to sports and recreation, respectively. ${ }^{35,36}$ The percentages of sports injuries in Taipei (3.4\%), Aragon, Spain (1.9\%) and Thessaloniki, Greece (4\%) were significantly lower. ${ }^{33,34,36}$ Fourteen percent of injuries were due to violence in the Northwestern Kentucky and Southern Indiana region, a percentage much higher than in all other regions $(0.8 \%-4.6 \%) .{ }^{32}$ Finally, the number of injuries due to suicide attempts was typically very low. ${ }^{28,31,34,35,37}$ The region with the highest percentage of injuries due to suicide attempts was the Rhone-Alpes region $(4.3 \%) .{ }^{14}$

Injuries to the cervical spine were the most frequent in all regions and cities. In Stockholm, Sweden and Aragon, Spain, however, there was a greater number of thoracic injuries compared to cervical spine injuries. ${ }^{33,36}$

\section{Countries}

Twenty-one studies discussed the incidence of SCI at a national level, including in 13 European countries (Denmark, Estonia [n=2], Finland, France, Greenland, Iceland, Ireland, the Netherlands, Norway, Romania, Spain [n=2], Switzerland and Turkey), four Asia Pacific countries (Japan, New Zealand, Australia, Fiji), Jordan, and the United States of America. ${ }^{11,30,38-56}$ Figure 6 is a map of injury causation. ${ }^{57}$

Table 3 displays how each study defined SCI and the sources used to estimate incidence. The majority used diagnostic codes. ${ }^{11,30,38,40,41,45,48,52,54}$ In addition to ICD-9 806 and 


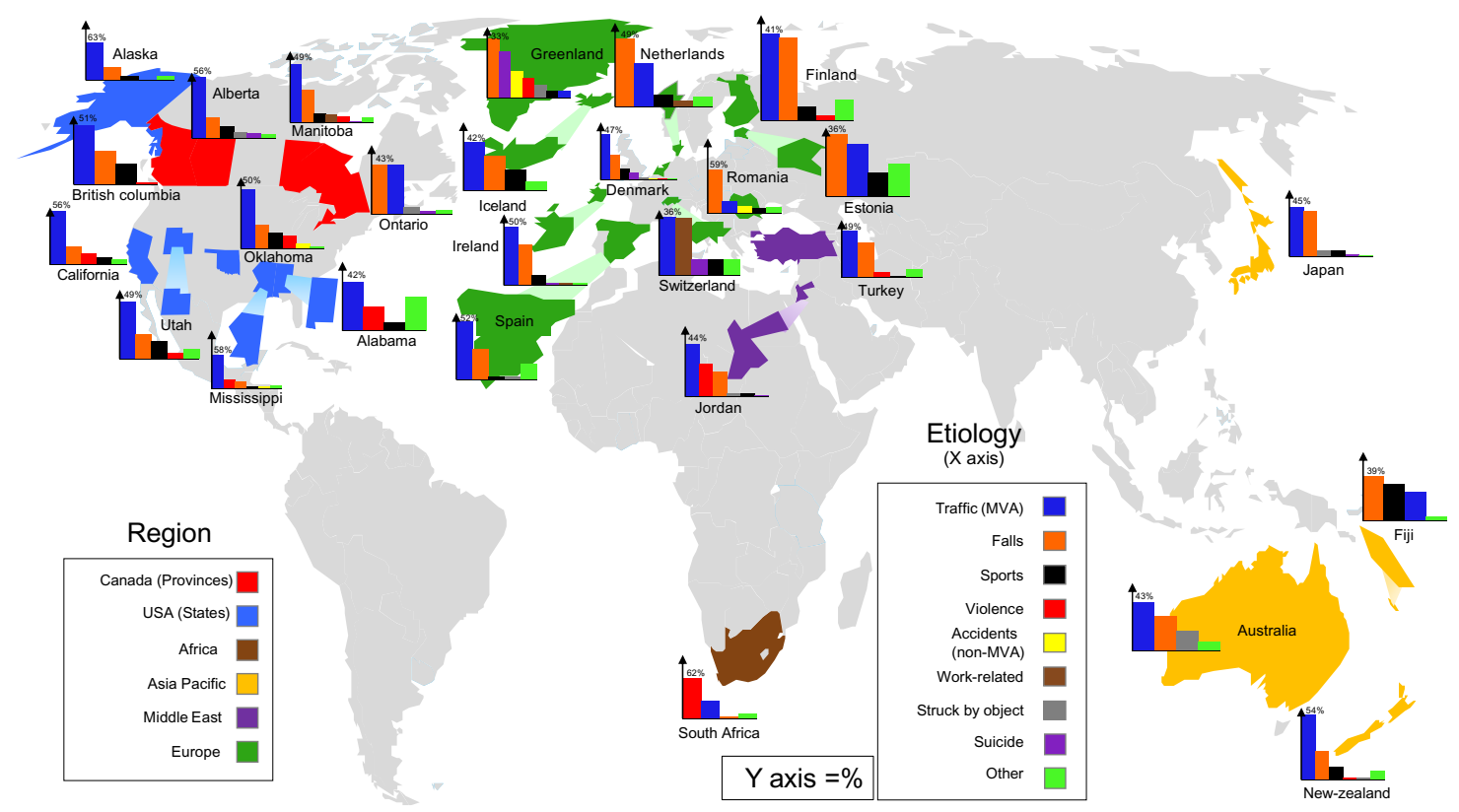

Figure 6 Causation of spinal cord injury in various countries.

Notes: A global map illustrating the causation of $\mathrm{SCl}$ between regions. The $y$-axis of the bar graphs indicates the percentage of contribution, while the $\mathrm{x}$-axis categorizes the reported etiologies from highest to lowest from left to right (except for other causes, which is represented on the far right). Sports included diving. Violence included both gunshot and stab wounds resulting in $\mathrm{SCl}$. Accidents represent all nontraffic accidents, including falling weight and crushing accidents.

Abbreviations: MVA, motor vehicle accidents; $\mathrm{SCl}$, spinal cord injury.

952 codes, a study based in New Zealand used ICD-9 codes 907 (late effects of SCI), 342 (hemiplegia), 344 (other paralytic syndromes), 805, 839 (other, multiple, and ill-defined dislocations), and 953 (injury to nerve roots and spinal plexus), and a study from Iceland used ICD-9 code 907 to detect other or incorrectly coded SCI cases. ${ }^{11,54}$ In the study by Ahoniemi et al, ICD-9 codes were used in 1995, ICD-10 codes in 1996, and S14-S34 after 1996. ${ }^{41}$ In Estonia, SCI was detected using an extensive list of ICD-10 codes. ${ }^{40}$

In the United States, the national incidence of SCI was estimated using data from the National Center for Health Statistics - Hospital Discharge Survey, which contains discharge records from selected nationwide hospitals. ${ }^{38}$ Many other studies identified SCI patients using records from several hospitals, rehabilitation units, orthopedic and neurosurgery departments, and emergency medical services. In contrast, some studies used information from a small list of hospitals or rehabilitation centers, as in some countries there are only a few facilities responsible for managing acute injuries. For example, in Ireland, data from the National Rehabilitation Hospital was used to determine incidence, as it receives all transfers from the main neurosurgery and orthopedic centers in Dublin and Cork. ${ }^{44}$ Interestingly, patients in Greenland requiring specialized SCI treatment are referred to the Rigshospitalet in Denmark and transferred to Hornbaek following surgery. Similarly, all patients injured in Denmark are admitted to either Hornbaek or Hald Ege rehabilitation institutions, depending on whether they live in East or West Denmark. ${ }^{39}$ Therefore, data from the Hornbaek center has been used to estimate incidence of SCI in both Denmark and Greenland.

Table 6 displays the annual incidence of SCI per million, the male-to-female ratio, peak age, causation, and level of injury for these countries. There was an upward trend in the incidence of SCI in the United States from 29.1 per million in 1970 to 42.8 per million in 1977 , with a peak incidence of 47.6 per million in $1977 .{ }^{38}$ In New Zealand and Switzerland, there was also a steady increase in the incidence or number of cases (43.3 per million in 1979-1988 to 49 per million in 1988; 56 cases in 1960 to 81 in 1966 , respectively). ${ }^{49,54}$ In Fiji, the incidence tripled from 5.6 per million in 1986 to 17.9 per million in $1991 .{ }^{55}$ In contrast, in Spain, there was a reduction in age-standardized incidence between 2000 and 2009. ${ }^{48}$ However, in comparison to numbers estimated in the $1980 \mathrm{~s}$, there was a drastic increase from 8.0 per million in $1984-1985$ to 23.5 per million between 2000 and 2009. ${ }^{56}$ In Romania, the number of cases with SCI was relatively stable between 1981 and 1990 (233-270 new cases) but dropped significantly to 105 in $1991 .{ }^{47}$ There was no significant change in estimates in Finland over three decades or in Iceland between 1980 and 1994. ${ }^{11,41}$ In Iceland between 2005 and 2009, however, the 
Table 6 Incidence and causation of spinal cord injury in countries

\begin{tabular}{|c|c|c|c|c|c|}
\hline & $\begin{array}{l}\text { Annual incidence } \\
\text { (per million) }\end{array}$ & $\begin{array}{l}\text { Male:female } \\
\text { ratio }\end{array}$ & Peak age & Causation & Level of injury \\
\hline $\begin{array}{l}\text { United States of America } \\
(1970-1977)^{38}\end{array}$ & 40.1 & $2.25: 1$ & Overall: 15-24 (68.0/million) & Not specified & Not specified \\
\hline \multirow[t]{8}{*}{ Denmark (1975-1984) } & 9.2 & 3.3:1 & Overall: 15-24 (40\%) & Traffic: $47 \%$ & Cervical: $51 \%$ \\
\hline & & & & Falls: $26 \%$ & Thoracic: $28 \%$ \\
\hline & & & & Sports: $12 \%$ & Lumbar: $21 \%$ \\
\hline & & & & Suicide: $8 \%$ & \\
\hline & & & & Struck by object: $3 \%$ & \\
\hline & & & & Crushing accident: $2 \%$ & \\
\hline & & & & Violence: $2 \%$ & \\
\hline & & & & Other: I\% & \\
\hline \multirow[t]{4}{*}{ Estonia $(|997-200|)^{30}$} & 35.4 & $6: 1$ & Males: 50-59 ( 32/million) & Falls: $36.5 \%$ & Cervical: $60.5 \%$ \\
\hline & & & Females: $30-39$ ( 15/million) & Traffic: $30.3 \%$ & Thoracic: $18.9 \%$ \\
\hline & & & & Sports: $13.9 \%$ & Lumbar: $20.6 \%$ \\
\hline & & & & Other: $19.3 \%$ & \\
\hline \multirow[t]{3}{*}{ Estonia $(1997-2007)^{40}$} & 39.7 & $5.5: 1$ & Males: 20-29 (I33.9/million) & Falls: $41.0 \%$ & Cervical: $59.4 \%$ \\
\hline & & & Females: $30-39$ (I8.3/million) & Traffic: $29.4 \%$ & Thoracic: $18.3 \%$ \\
\hline & & & & & Lumbar/sacral: $22.3 \%$ \\
\hline \multirow{5}{*}{ Finland $(1976-2005)^{41}$} & 13.8 & $4.5-5.1: 1$ & Males: 16-34 & Falls: $41.2 \%$ & Not specified \\
\hline & & & Females: 16-34 & Traffic: $39.5 \%$ & \\
\hline & & & & Diving: $6.6 \%$ & \\
\hline & & & & Violence: $2.7 \%$ & \\
\hline & & & & Other: $10.0 \%$ & \\
\hline France $(2000)^{42}$ & 19.4 & Not specified & Not specified & Not specified & Not specified \\
\hline \multirow[t]{7}{*}{ Greenland (1965-1986) ${ }^{43}$} & 26 & $2.86: 1$ & Not specified & Falls: $33.3 \%$ & Not specified \\
\hline & & & & Suicide: $26 \%$ & \\
\hline & & & & Accidental shot: $15 \%$ & \\
\hline & & & & Violence: II\% & \\
\hline & & & & Struck by object: $7.4 \%$ & \\
\hline & & & & Sports: $3.7 \%$ & \\
\hline & & & & Traffic: $3.7 \%$ & \\
\hline \multirow{4}{*}{ Iceland (1975-2009)" } & 22.6 & $2.6: 1$ & Overall: $\leq 30(43 \%)$ & Traffic: $42.5 \%$ & Cervical: $57 \%$ \\
\hline & & & & Falls: $30.9 \%$ & Thoracic/lumbar: $43 \%$ \\
\hline & & & & Sports: $19 \%$ & \\
\hline & & & & Other: $8 \%$ & \\
\hline \multirow[t]{6}{*}{ Ireland $(2000)^{44}$} & 13.1 & $6.7: 1$ & Overall: $20-29$ & Traffic: $50 \%$ & Cervical: $50 \%$ \\
\hline & & & & Falls: $35 \%$ & Thoracic: $41 \%$ \\
\hline & & & & Sports: $9 \%$ & Lumbar: $9 \%$ \\
\hline & & & & Suicide: $2 \%$ & \\
\hline & & & & Work-related: $2 \%$ & \\
\hline & & & & latrogenic: $2 \%$ & \\
\hline \multirow[t]{6}{*}{ The Netherlands $(1994)^{45}$} & 12.1 & 3.3:1 & Overall: 2 I-30 (24.8\%) & Falls: $48.7 \%$ & Not specified \\
\hline & & & & Traffic: $31.0 \%$ & \\
\hline & & & & Sports: $8.9 \%$ & \\
\hline & & & & Occupational: $4.4 \%$ & \\
\hline & & & & Other: $3.5 \%$ & \\
\hline & & & & Unknown: $3.5 \%$ & \\
\hline \multirow[t]{4}{*}{ Norway $(1974-1975)^{46}$} & 16.5 & $4.9: 1$ & Overall: $20-40$ (39\%) & Not specified & Cervical: $53 \%$ \\
\hline & & & & & Thoracic: $26 \%$ \\
\hline & & & & & Lumbar: I2\% \\
\hline & & & & & Conus/cauda equina: $9 \%$ \\
\hline \multirow[t]{5}{*}{ Romania $(1975-1993)^{47}$} & 28.5 & $3.35: 1$ & Overall: $5 \mathrm{I}-60$ (2I.4\%) & Falls: $59 \%$ & Cervical: $57.2 \%$ \\
\hline & & & & Traffic: $16 \%$ & Thoracic: $29.3 \%$ \\
\hline & & & & Falling weight: $10 \%$ & Lumbar: $13.0 \%$ \\
\hline & & & & Sports: $7 \%$ & Sacral: $0.4 \%$ \\
\hline & & & & Other: $8 \%$ & \\
\hline
\end{tabular}

(Continued) 
Table 6 (Continued)

\begin{tabular}{|c|c|c|c|c|c|}
\hline & $\begin{array}{l}\text { Annual incidence } \\
\text { (per million) }\end{array}$ & $\begin{array}{l}\text { Male:female } \\
\text { ratio }\end{array}$ & Peak age & Causation & Level of injury \\
\hline Spain $(1984-1985)^{56}$ & 8.0 & $\begin{array}{l}\text { Not specified } \\
\text { for traumatic } \\
\text { cases alone }\end{array}$ & $\begin{array}{l}\text { Not specified for traumatic } \\
\text { cases alone }\end{array}$ & $\begin{array}{l}\text { Traffic: } 52 \% \\
\text { Falls: } 27.5 \% \\
\text { Stroke: } 6 \% \\
\text { Surgical: } 4 \% \\
\text { Sports: } 3 \% \\
\text { Projectile: } 3 \% \\
\text { Others: } 4.5 \%\end{array}$ & $\begin{array}{l}\text { Not specified for } \\
\text { traumatic cases alone }\end{array}$ \\
\hline Spain $(2000-2009)^{48}$ & 23.5 & Not specified & Not specified & Traffic: $35.5 \%$ & Not specified \\
\hline Switzerland (1960-1967) ${ }^{49}$ & $\sim 15$ & $\sim 5: 1$ & Overall: $20-29$ (29\%) & $\begin{array}{l}\text { Traffic: } 36 \% \\
\text { Work: } 35 \% \\
\text { Suicide: } 9.67 \% \\
\text { Sports: } 9.67 \% \\
\text { Other: } 9.67 \%\end{array}$ & Not specified \\
\hline Turkey $(1992)^{50}$ & 12.7 & $2.5: 1$ & Overall: 20-29 (23/million) & $\begin{array}{l}\text { Traffic: } 48.8 \% \\
\text { Falls: } 36.5 \% \\
\text { Violence: } 5.2 \% \\
\text { Sports: } 1.2 \%\end{array}$ & $\begin{array}{l}\text { Cervical: } 31.7 \% \\
\text { Thoracic: } 26.6 \% \\
\text { Lumbar: } 28.1 \%\end{array}$ \\
\hline Jordan $(1988-1993)^{51}$ & 18 & 5.8:1 & Overall: $21-30$ (35.8\%) & $\begin{array}{l}\text { Traffic: } 44.4 \% \\
\text { Violence: } 27.8 \% \\
\text { Falls: } 2 \text { I. } 2 \% \\
\text { Struck by object: } 3.3 \% \\
\text { Sports: } 2.6 \% \\
\text { Suicide: } 0.7 \%\end{array}$ & $\begin{array}{l}\text { Cervical: } 31.8 \% \\
\text { Thoracic/lumbar: } 68.2 \%\end{array}$ \\
\hline Japan $(1990)^{52}$ & 39.4 & 4.3:1 & Overall: 50-59 (2I.2\%) & $\begin{array}{l}\text { Traffic: } 44.6 \% \\
\text { Falls: } 41 \% \\
\text { Struck by object: } 6.0 \% \\
\text { Sports: } 5.3 \% \\
\text { Suicide: } 1.7 \% \\
\text { Other: } 1.4 \%\end{array}$ & $\begin{array}{l}\text { Cervical: } 74.3 \% \\
\text { Thoracic or } \\
\text { below: } 25.5 \% \\
\text { Unknown: } 0.2 \%\end{array}$ \\
\hline Australia (1998-1999) 53 & 14.5 & $3.2: 1$ & $\begin{array}{l}\text { Males: I5-24 ( } \sim 38 / \text { million }) \\
\text { Females: I5-24 ( } 16 / \text { million })\end{array}$ & $\begin{array}{l}\text { Traffic: } 43 \% \\
\text { Falls: } 31 \% \\
\text { Sports: } 5 \%\end{array}$ & $\begin{array}{l}\text { Cervical: } 57.7 \% \\
\text { Thoracic: } 24.9 \% \\
\text { Lumbar: } 16.6 \% \\
\text { Sacral: } 0.75 \%\end{array}$ \\
\hline New Zealand (1979-1988)54 & 49.1 & Not specified & $\begin{array}{l}\text { Overall: } 15-29 \text { (104/million } \\
\text { in 1988); } 96.7 / \text { million in } \\
\text { 1979-1988 }\end{array}$ & $\begin{array}{l}\text { Traffic: } 54 \% \\
\text { Falls: } 24 \% \\
\text { Sports: } 11 \% \\
\text { Machinery: } 3 \% \\
\text { Exertion: } 3 \% \\
\text { Struck by object: } 2 \% \\
\text { Violence: } 2 \% \\
\text { Other: } 2 \%\end{array}$ & $\begin{array}{l}\text { Cervical: } 52.3 \% \\
\text { Thoracic: } 25.2 \% \\
\text { Lumbar: } 21.8 \% \\
\text { Sacral: } 0.66 \%\end{array}$ \\
\hline Fiji $(1985-1994)^{55}$ & 10.0 & $6.7: 1$ & $\begin{array}{l}\text { Males: } 16-30 \\
\text { Females: } 16-30\end{array}$ & $\begin{array}{l}\text { Falls: } 38.7 \% \\
\text { Sports: } 32 \% \\
\text { Traffic: } 25.3 \% \\
\text { Other: } 4 \%\end{array}$ & $\begin{array}{l}\text { Not specified for } \\
\text { traumatic cases alone }\end{array}$ \\
\hline
\end{tabular}

incidence significantly increased to 33.5 per million from 21 per million in 2000-2004. ${ }^{11}$

The countries with the highest reported incidences were the United States (40.1 per million), Estonia (35.4 per million and 39.7 per million), Japan (39.4 per million), and New Zealand (49.1 per million). ${ }^{30,38,40,52,54}$ In Japan, there is an increased prevalence of ossification of the posterior longitudinal ligament (OPLL) in the elderly and congenital stenosis. ${ }^{52}$ The population is therefore at an increased risk of sustaining a SCI following a traumatic accident. In Estonia, it is speculated that the rates are higher because there is less regulation and enforcement of road safety rules, higher alcohol consumption, and a flatter landscape, enabling vehicles to drive at more dangerous speeds. ${ }^{30}$ 
In the United States of America, these higher figures are likely due to increased violence, aggressive driving, or riding without seat belts and poor road conditions. ${ }^{38}$ Dixon et al acknowledged that New Zealand has a higher incidence of SCI than many other countries, but also hypothesized that this may be as a result of the methodology used to calculate rates. ${ }^{54}$

The incidence of SCI in New Zealand was much higher than in Australia (14.5 per million) and Fiji (10 per million). ${ }^{53-55}$

The highest incidence of SCI in Europe was in Estonia, followed by Romania (28.5 per million), Spain (23.5 per million), and France (19.4 per million). ${ }^{42,47,48}$ The lowest rate in Europe was in Denmark (9.2 per million), followed by the Netherlands, (12.1 per million), Turkey (12.7 per million), Ireland (13.1 per million), Switzerland ( $\sim 15$ per million), Finland (13.8 per million), and Norway (16.5 per million). ${ }^{39,41,44} 46,49,50$ Iceland and Greenland had similar estimates of 22.6 per million and 26 per million, respectively. ${ }^{11}$

In all countries, there was a greater percentage of males with SCI than females. The male:female ratio, however, varied significantly across countries, with the highest ratios in Fiji (6.7:1), Ireland (6.7:1), Estonia (5.5:1, 6:1) and Jordan (5.8:1) and the lowest in Iceland (2.6:1), Turkey (2.5:1), and the United States $(2.25: 1) .{ }^{11,30,38,40,44,50,51,55}$ In all countries, the age of peak incidence was 15-30, with the exception of Romania (51-60 years), Japan (50-59 years), and females in Estonia (30-39 years), where more injuries were seen in the elderly and were due to falls..$^{30,40,47,52}$

In general, traffic accidents were the primary cause of SCI in studied countries (36\%-59\%). In Estonia, Finland, Greenland, Fiji, the Netherlands, and Romania, however, falls were responsible for the greatest percentage of SCI. In other countries, falls were typically the second most common etiology. In Greenland, $26 \%$ of injuries were due to suicide, a percentage significantly greater than other countries. ${ }^{43}$ Twenty-eight percent and $11 \%$ of SCIs were due to violence in Jordan and Greenland, respectively. ${ }^{43,51}$ In Romania, a shockingly high $10 \%$ of injuries were caused by a falling weight. ${ }^{47}$ Injuries related to sports were the most common in Fiji (32\%) and Iceland (19\%). ${ }^{11,55}$

\section{Discussion}

SCI affects a patient's physical, social, and psychological well-being and places a substantial burden on health care systems, families, and communities. An understanding of the prevalence and incidence of SCI enables health care systems to implement preventative strategies and allocate resources appropriately for disease management. In addition, by observing trends in SCI incidence over time, such as the decrease seen in Spain or the increase in the United States, systems can gather feedback as to what preventative measures have worked.

Based on this review, we have identified nine studies that have reported on the prevalence and 44 studies that have discussed the incidence of acute SCI. The prevalence of SCI was the highest in the United States of America (906 per million) and the lowest in the Rhone-Alpes region, France (250 per million) and Helsinki, Finland (280 per million). With respect to states and provinces, the incidence of SCI was the highest in Alaska ( 83 per million) and Mississippi ( 77 per million) and the lowest in Alabama (29.4 per million), despite a large percentage of violence injuries (21.2\%). Incidences were above 50 per million in Hualien County in Taiwan (56.1 per million), the central Portugal region (58 per million), and Olmsted County in Minnesota (54.8 per million) and were lower than 20 per million in Taipei, Taiwan (14.6 per million), the Rhone-Alpes region in France (12.7 per million), Aragon, Spain (12.1 per million), Southeast Turkey (16.9 per million), and Stockholm, Sweden (19.5 per million). The highest national incidence was 49.1 per million in New Zealand, and the lowest incidence was in Fiji (10.0 per million) and Spain (1984-1985: 8.0 per million). The majority of studies showed a high male-to-female ratio and an age of peak incidence of younger than 30 years old. Traffic accidents were typically the most common cause of SCI, followed by falls in the elderly population.

As the population ages, it is important to observe trends in the age of peak incidence, as this may change. Currently, in most regions and countries, a larger percentage of SCI patients are under the age of 30 . One of the exceptions to this trend was in Japan, where the majority of the patients sustaining SCIs were over the age of 50 years. ${ }^{52}$ This is primarily due to early spinal degenerative changes, specifically OPLL, as well as an increased prevalence of congenital stenosis, causing a higher risk of SCI following a traumatic event. ${ }^{58}$ Degeneration of various components of the vertebra is common in the elderly population and may lead to narrowing of the spinal canal. ${ }^{59}$ In turn, these degenerative changes place people at a greater risk of suffering SCI following a fall or another traumatic event. ${ }^{58}$ Therefore, with the aging of the population, acute care systems may be confronted with an increased number of elderly patients with SCI and should plan and allocate resources accordingly. ${ }^{59}$

The rates of SCIs vary across countries, regions, and cities. This could be a reflection of actual differences in incidence or a result of differences in case ascertainment. For example, 
some studies have used information from death certificates, coroners, or the department of legal medicine to include SCI victims who have died at the scene of the accident or during transport to acute care centers. Other studies have excluded these patients from their estimates. In addition, identification of patients with acute SCI was done in different ways across studies. Some used ICD-9 or ICD-10 codes to detect relevant patients, whereas others used a simple clinical definition, surveys, or questionnaires. In order to make comparisons between countries or to accurately estimate global incidence, methodologies of data collection must be standardized.

It is also challenging to compare differences in SCI causation across countries due to a lack of standard definitions. For example, some studies have defined motor vehicle accidents as any collision involving a motorized vehicle, including hitting a pedestrian or cyclist, whereas other studies have separated accidents involving pedestrians into a separate category. Another example is sport injuries: some studies have combined diving and other sporting activities into a single category, while others have divided these two into separate categories. In this review, we have attempted to standardize these definitions in order to make comparisons.

This review summarizes what is currently known in the literature on the incidence and prevalence of SCI.

\section{Disclosure}

The authors report no conflicts of interest in this work.

\section{References}

1. Furlan JC, Noonan V, Singh A, Fehlings MG. Assessment of impairment in patients with acute traumatic spinal cord injury: a systematic review of the literature. J Neurotrauma. 2011;28(8):1445-1477.

2. Noonan VK, Fingas M, Farry A, et al. Incidence and prevalence of spinal cord injury in Canada: a national perspective. Neuroepidemiology. 2012;38(4):219-226.

3. Sekhon LH, Fehlings MG. Epidemiology, demographics, and pathophysiology of acute spinal cord injury. Spine (Phila Pa 1976). 2001;26(Suppl 24): S2-S12.

4. Krueger H, Noonan VK, Trenaman LM, Joshi P, Rivers CS. The economic burden of traumatic spinal cord injury in Canada. Chronic Dis Inj Can. 2013;33(3):113-122.

5. Cripps RA, Lee BB, Wing P, Weerts E, Mackay J, Brown D. A global map for traumatic spinal cord injury epidemiology: towards a living data repository for injury prevention. Spinal Cord. 2011;49(4): 493-501.

6. Wyndaele M, Wyndaele JJ. Incidence, prevalence and epidemiology of spinal cord injury: what learns a worldwide literature survey? Spinal Cord. 2006;44(9):523-529.

7. Blumer CE, Quine S. Prevalence of spinal cord injury: an international comparison. Neuroepidemiology. 1995;14(5):258-268.

8. DeVivo MJ, Fine PR, Maetz HM, Stover SL. Prevalence of spinal cord injury: a reestimation employing life table techniques. Arch Neurol. 1980;37(11):707-708.

9. Harvey C, Rothschild BB, Asmann AJ, Stripling T. New estimates of traumatic SCI prevalence: a survey-based approach. Paraplegia. 1990;28(9):537-544.
10. O'Connor PJ. Prevalence of spinal cord injury in Australia. Spinal Cord. 2005;43(1):42-46.

11. Knútsdóttir S, Thórisdóttir H, Sigvaldason K, Jónsson H, Björnsson A, Ingvarsson P. Epidemiology of traumatic spinal cord injuries in Iceland from 1975 to 2009. Spinal Cord. 2012;50(2):123-126.

12. Dahlberg A, Kotila M, Leppänen P, Kautiainen H, Alaranta H. Prevalence of spinal cord injury in Helsinki. Spinal Cord. 2005;43(1):47-50.

13. Hagen EM, Eide GE, Rekand T, Gilhus NE, Gronning M. A 50-year follow-up of the incidence of traumatic spinal cord injuries in Western Norway. Spinal Cord. 2010;48(4):313-318.

14. Minaire P, Demolin P, Bourret J, et al. Life expectancy following spinal cord injury: a ten-years survey in the Rhône-Alpes Region, France, 1969-1980. Paraplegia. 1983;21(1):11-15.

15. Griffin MR, Opitz JL, Kurland LT, Ebersold MJ, O'Fallon WM. Traumatic spinal cord injury in Olmsted County, Minnesota, 1935-1981. Am J Epidemiol. 1985;121(6):884-895.

16. Rahimi-Movaghar V, Saadat S, Rasouli MR, et al. Prevalence of spinal cord injury in Tehran, Iran. J Spinal Cord Med. 2009;32(4): $428-431$.

17. Kurtzke JF. Epidemiology of spinal cord injury. Exp Neurol. 1975; 48(3 pt 2):163-236.

18. Lenehan B, Street J, Kwon BK, et al. The epidemiology of traumatic spinal cord injury in British Columbia, Canada. Spine (Phila Pa 1976). 2012;37(4):321-329.

19. Dryden DM, Saunders LD, Rowe BH, et al. The epidemiology of traumatic spinal cord injury in Alberta, Canada. Can J Neurol Sci. 2003;30(2):113-121.

20. Pickett W, Simpson K, Walker J, Brison RJ. Traumatic spinal cord injury in Ontario, Canada. J Trauma. 2003;55(6):1070-1076.

21. McCammon JR, Ethans K. Spinal cord injury in Manitoba: a provincial epidemiological study. J Spinal Cord Med. 2011;34(1):6-10.

22. Price C, Makintubee S, Herndon W, Istre GR. Epidemiology of traumatic spinal cord injury and acute hospitalization and rehabilitation charges for spinal cord injuries in Oklahoma, 1988-1990. Am J Epidemiol. 1994;139(1):37-47.

23. Warren S, Moore M, Johnson MS. Traumatic head and spinal cord injuries in Alaska (1991-1993). Alaska Med. 1995;37(1):11-19.

24. Thurman DJ, Burnett CL, Jeppson L, Beaudoin DE, Sniezek JE. Surveillance of spinal cord injuries in Utah, USA. Paraplegia. 1994;32(10):665-669.

25. Surkin J, Gilbert BJ, Harkey HL 3rd, Sniezek J, Currier M. Spinal cord injury in Mississippi. Findings and evaluation, 1992-1994. Spine (Phila Pa 1976). 2000;25(6):716-721.

26. Fine PR, Kuhlemeier KV, DeVivo MJ, Stover SL. Spinal cord injury: an epidemiologic perspective. Paraplegia. 1979;17(2):237-250.

27. Kraus JF, Franti CE, Riggins RS, Richards D, Borhani NO. Incidence of traumatic spinal cord lesions. J Chronic Dis. 1975;28(9):471-492.

28. Karamehmetoğlu SS, Nas K, Karacan I, et al. Traumatic spinal cord injuries in southeast Turkey: an epidemiological study. Spinal Cord. 1997;35(8):531-533.

29. Martins F, Freitas F, Martins L, Dartigues JF, Barat M. Spinal cord injuries - epidemiology in Portugal's central region. Spinal Cord. 1998;36(8):574-578.

30. Sabre L, Hagen EM, Rekand T, Asser T, Kõrv J. Traumatic spinal cord injury in two European countries: why the differences? Eur J Neurol. 2013;20(2):293-299.

31. Lan C, Lai JS, Chang KH, Jean YC, Lien IN. Traumatic spinal cord injuries in the rural region of Taiwan: an epidemiological study in Hualien county, 1986-1990. Paraplegia. 1993;31(6):398-403.

32. Burke DA, Linden RD, Zhang YP, Maiste AC, Shields CB. Incidence rates and populations at risk for spinal cord injury: A regional study. Spinal Cord. 2001;39(5):274-278.

33. van Den Berg M, Castellote JM, Mahillo-Fernandez I, de PedroCuesta J. Incidence of traumatic spinal cord injury in Aragón, Spain (1972-2008). J Neurotrauma. 2011;28(3):469-477.

34. Chen CF, Lien IN. Spinal cord injuries in Taipei, Taiwan, 1978-1981. Paraplegia. 1985;23(6):364-370. 
35. Silberstein B, Rabinovich S. Epidemiology of spinal cord injuries in Novosibirsk, Russia. Paraplegia. 1995;33(6):322-325.

36. Divanoglou A, Levi R. Incidence of traumatic spinal cord injury in Thessaloniki, Greece and Stockholm, Sweden: a prospective populationbased study. Spinal Cord. 2009;47(11):796-801.

37. Pickett GE, Campos-Benitez M, Keller JL, Duggal N. Epidemiology of traumatic spinal cord injury in Canada. Spine (Phila Pa 1976). 2006;31(7):799-805.

38. Bracken MB, Freeman DH Jr. Hellenbrand K. Incidence of acute traumatic hospitalized spinal cord injury in the United States, 1970-1977. Am J Epidemiol. 1981;113(6):615-622.

39. Biering-Sørensen E, Pedersen V, Clausen S. Epidemiology of spinal cord lesions in Denmark. Paraplegia. 1990;28(2):105-118.

40. Sabre L, Pedai G, Rekand T, Asser T, Linnamägi U, Kõrv J. High incidence of traumatic spinal cord injury in Estonia. Spinal Cord. 2012;50(10):755-759.

41. Ahoniemi E, Alaranta H, Hokkinen EM, Valtonen K, Kautiainen H. Incidence of traumatic spinal cord injuries in Finland over a 30-year period. Spinal Cord. 2008;46(12):781-784.

42. Albert T, Ravaud JF; Tetrafigap group. Rehabilitation of spinal cord injury in France: a nationwide multicentre study of incidence and regional disparities. Spinal Cord. 2005;43(6):357-365.

43. Pedersen V, Müller PG, Biering-Sørensen F. Traumatic spinal cord injuries in Greenland 1965-1986. Paraplegia. 1989;27(5):345-349.

44. O'Connor RJ, Murray PC. Review of spinal cord injuries in Ireland. Spinal Cord. 2006;44(7):445-448.

45. van Asbeck FW, Post MW, Pangalila RF. An epidemiological description of spinal cord injuries in The Netherlands in 1994. Spinal Cord. 2000;38(7):420-424.

46. Gjone R, Nordlie L. Incidence of traumatic paraplegia and tetraplegia in Norway: a statistical survey of the years 1974 and 1975. Paraplegia. 1978;16(1):88-93.

47. Soopramanien A. Epidemiology of spinal injuries in Romania. Paraplegia. 1994;32(11):715-722.
48. Pérez K, Novoa AM, Santamariña-Rubio E, et al; Working Group for Study of Injuries of Spanish Society of Epidemiology. Incidence trends of traumatic spinal cord injury and traumatic brain injury in Spain, 2000-2009. Accid Anal Prev. 2012;46:37-44.

49. Gehrig R, Michaelis LS. Statistics of acute paraplegia and tetraplegia on a national scale. Switzerland 1960-1967. Paraplegia. 1968;6(2): 93-95.

50. Karacan I, Koyuncu H, Pekel O, et al. Traumatic spinal cord injuries in Turkey: a nation-wide epidemiological study. Spinal Cord. 2000;38(11): 697-701.

51. Otom AS, Doughan AM, Kawar JS, Hattar EZ. Traumatic spinal cord injuries in Jordan - an epidemiological study. Spinal Cord. 1997;35(4): 253-255.

52. Shingu H, Ikata T, Katoh S, Akatsu T. Spinal cord injuries in Japan: a nationwide epidemiological survey in 1990. Paraplegia. 1994;32(1): 3-8.

53. O'Connor P. Incidence and patterns of spinal cord injury in Australia. Accid Anal Prev. 2002;34(4):405-415.

54. Dixon GS, Danesh JN, Caradoc-Davies TH. Epidemiology of spinal cord injury in New Zealand. Neuroepidemiology. 1993;12(2): $88-95$.

55. Maharaj JC. Epidemiology of spinal cord paralysis in Fiji: 1985-1994. Spinal Cord. 1996;34(9):549-559.

56. Garcia-Reneses J, Herruzo-Cabrera R, Martinez-Moreno M. Epidemiological study of spinal cord injury in Spain 1984-1985. Paraplegia. 1991;29:180-190.

57. Hart C, Williams E. Epidemiology of spinal cord injuries: a reflection of changes in South African society. Paraplegia. 1994;32(11):709-714.

58. Rhee JM, Shamji MF, Erwin WM, et al. Nonoperative management of cervical myelopathy: a systematic review. Spine (Phila Pa 1976). 2013;38(22 Suppl 1):S55-S67.

59. Fehlings MG, Tetreault LA, Wilson JR, Skelly AC. Cervical spondylotic myelopathy: current state of the art and future directions. Spine (Phila Pa 1976). 2013;38(22 Suppl 1):S1-S8. 


\section{Supplementary materials}

Table SI Detailed overview how each study was rated

\begin{tabular}{|c|c|c|c|c|c|c|c|c|c|c|c|}
\hline Author & $\mathbf{I}$ & 2 & 3 & 4 & 5 & 6 & 7 & 8 & 9 & 10 & Total score \\
\hline \multicolumn{12}{|l|}{ Incidence Studies } \\
\hline \multicolumn{12}{|c|}{ States and provinces of the United States and Canada } \\
\hline Pickett et al' & & & $\mathrm{X}$ & & & & $\mathrm{x}$ & & & & 8 \\
\hline McCammon and Ethans ${ }^{2}$ & $x$ & $\mathrm{x}$ & $x$ & $x$ & & $x$ & $x$ & & $\mathrm{x}$ & & 3 \\
\hline Dryden et $\mathrm{al}^{3}$ & & $\mathrm{x}$ & & $x$ & & $x$ & & & & & 7 \\
\hline Lenehan et $\mathrm{al}^{4}$ & & $x$ & & & & & $x$ & & $x$ & & 7 \\
\hline Price et $\mathrm{al}^{5}$ & & $x$ & & & $x$ & & $x$ & & $x$ & & 6 \\
\hline Surkin et $\mathrm{al}^{6}$ & $x$ & $x$ & & & & & & & $x$ & & 7 \\
\hline Thurman et $\mathrm{al}^{7}$ & & $x$ & & $x$ & & $x$ & & & $x$ & & 6 \\
\hline Warren et $\mathrm{al}^{8}$ & $x$ & $x$ & & & & & & & $x$ & & 7 \\
\hline Kraus et $\mathrm{al}^{9}$ & & $x$ & & $x$ & & $x$ & & & $x$ & & 6 \\
\hline Fine et $\mathrm{al}^{10}$ & $x$ & $x$ & $x$ & $x$ & $x$ & $x$ & $x$ & & $x$ & $x$ & I \\
\hline \multicolumn{12}{|l|}{ Regions } \\
\hline Pickett et al' & & $x$ & & $x$ & & $x$ & $x$ & & & & 6 \\
\hline Burke et al ${ }^{12}$ & & $x$ & & $x$ & & $x$ & $x$ & & $x$ & & 5 \\
\hline Griffin et $\mathrm{al}^{13}$ & & $x$ & & $x$ & & $x$ & & & $x$ & & 6 \\
\hline Minaire et $\mathrm{al}^{14}$ & $x$ & $x$ & $x$ & $x$ & $x$ & $x$ & $x$ & & $x$ & & 2 \\
\hline Divanoglou and Levi' ${ }^{15}$ & & & & & & & $x$ & & & & 9 \\
\hline Hagen et al ${ }^{16}$ & & $x$ & & $x$ & & $x$ & $x$ & & & & 6 \\
\hline Martins et $\mathrm{al}^{17}$ & & $x$ & & $x$ & & $x$ & & & $x$ & & 6 \\
\hline Van den Berg et al ${ }^{18}$ & & $x$ & & $x$ & & $x$ & $x$ & & $x$ & & 5 \\
\hline Karamehmetoglu 19 & $x$ & $x$ & $x$ & $x$ & & $x$ & $x$ & & $x$ & & 3 \\
\hline Rahimi-Movaghar et al ${ }^{20}$ & & & $x$ & & $x$ & & & & & $x$ & 7 \\
\hline Silberstein and Rabinovich ${ }^{21}$ & $x$ & $x$ & $x$ & $x$ & & $x$ & $x$ & & $x$ & $x$ & 2 \\
\hline Chen et $\mathrm{a}^{22}$ & & $\mathrm{x}$ & & $x$ & & $x$ & $x$ & & $x$ & & 5 \\
\hline Lan et $\mathrm{al}^{23}$ & & $x$ & & $x$ & & $x$ & $x$ & & $x$ & & 5 \\
\hline \multicolumn{12}{|l|}{ Countries } \\
\hline Bracken et $\mathrm{al}^{24}$ & & $x$ & & $x$ & & $x$ & $x$ & & & & 6 \\
\hline Biering-Sorensen et $\mathrm{al}^{25}$ & & $x$ & $x$ & $x$ & $x$ & $x$ & $x$ & & $x$ & & 3 \\
\hline Sabre et $\mathrm{al}^{26}$ & & $x$ & & $x$ & & $x$ & $x$ & & & & 6 \\
\hline Ahoniemi et $\mathrm{a}^{27}$ & & $x$ & & $x$ & $x$ & $x$ & $x$ & & & & 5 \\
\hline Albert et $\mathrm{al}^{28}$ & & $x$ & & & $x$ & & $x$ & & $x$ & & 6 \\
\hline Pedersen et $\mathrm{al}^{29}$ & $x$ & $x$ & $x$ & $x$ & & $x$ & $x$ & & $x$ & & 3 \\
\hline Knuttsdottir et $\mathrm{al}^{30}$ & & $x$ & & $x$ & & $x$ & $x$ & & $x$ & & 5 \\
\hline O'Connor and Murray ${ }^{3 \prime}$ & & & $x$ & & $x$ & & $x$ & & $x$ & & 6 \\
\hline Van Asbeck et al ${ }^{32}$ & & $x$ & & & & & $x$ & & $x$ & & 7 \\
\hline Gjone et $\mathrm{al}^{33}$ & & $x$ & $x$ & $x$ & & $x$ & $x$ & & $x$ & & 4 \\
\hline Soopramanien ${ }^{34}$ & $x$ & $x$ & $x$ & $x$ & $x$ & $x$ & $x$ & & $x$ & & 2 \\
\hline Garcia-Reneses et $\mathrm{al}^{35}$ & $x$ & $x$ & $x$ & $x$ & $x$ & $x$ & $x$ & & $x$ & & 2 \\
\hline Perez et $\mathrm{al}^{36}$ & $x$ & $x$ & & & & & $x$ & & $x$ & & 6 \\
\hline Gehrig et $\mathrm{al}^{37}$ & & $x$ & $x$ & $x$ & & $x$ & $x$ & & $x$ & & 4 \\
\hline Karacan et al ${ }^{38}$ & & $x$ & & $x$ & & $x$ & $x$ & & $x$ & & 5 \\
\hline Sabre et $\mathrm{al}^{39}$ & & $x$ & & $x$ & & $x$ & $x$ & & & & 6 \\
\hline Otom ${ }^{40}$ & & $x$ & & $x$ & & $x$ & $x$ & & $x$ & & 5 \\
\hline Shingu et $\mathrm{al}^{41}$ & & $x$ & & $x$ & $x$ & $x$ & $x$ & & $x$ & & 4 \\
\hline$O^{\prime}$ Connor ${ }^{42}$ & & $x$ & & & & & $x$ & & $x$ & & 7 \\
\hline Maharaj ${ }^{43}$ & & $x$ & $x$ & $x$ & $x$ & $x$ & $x$ & & $x$ & & 3 \\
\hline $\operatorname{Dixon}^{44}$ & & $x$ & & $x$ & & $x$ & $x$ & & $x$ & & 5 \\
\hline \multicolumn{12}{|l|}{ Prevalence Studies } \\
\hline DeVivo et $\mathrm{al}^{45}$ & & $x$ & $x$ & & $x$ & & NA & & $x$ & & 6 \\
\hline Harvey et $\mathrm{al}^{46}$ & & $x$ & & & $x$ & & NA & & $x$ & $x$ & 6 \\
\hline $\mathrm{O}^{\prime}$ Connor et $\mathrm{al}^{47}$ & & $x$ & $x$ & & & & NA & & $x$ & & 7 \\
\hline Knútsdóttir et $\mathrm{al}^{30}$ & & $x$ & & $x$ & & $x$ & NA & & $x$ & & 6 \\
\hline Dahlberg et $\mathrm{al}^{48}$ & & $x$ & & $x$ & $x$ & $x$ & NA & & & & 6 \\
\hline Hagen et $\mathrm{al}^{16}$ & & $x$ & & $x$ & & $x$ & NA & & & & 7 \\
\hline Minaire et $\mathrm{al}^{14}$ & $x$ & $x$ & $x$ & $x$ & $x$ & $x$ & NA & & $x$ & & 3 \\
\hline Griffin et $\mathrm{al}^{13}$ & & $x$ & & $x$ & & $x$ & NA & $x$ & $x$ & & 5 \\
\hline Rahimi-Movaghar et $\mathrm{al}^{20}$ & & & $x$ & & $x$ & & NA & $x$ & & $x$ & 6 \\
\hline
\end{tabular}


Table S2 Description of the ICD codes

\begin{tabular}{|c|c|}
\hline ICD codes & Description \\
\hline \multicolumn{2}{|l|}{ ICD-8 } \\
\hline 344 & Other cerebral paralysis \\
\hline 805 & $\begin{array}{l}\text { Fracture and fracture dislocation of vertebral column } \\
\text { without mention of spinal cord lesion }\end{array}$ \\
\hline 806 & Fracture of vertebral column with spinal cord injury \\
\hline 958 & Spinal cord lesion without evidence of spinal bone injury \\
\hline \multicolumn{2}{|l|}{ ICD-9 } \\
\hline 805 & $\begin{array}{l}\text { Fracture of the vertebral column without mention of } \\
\text { spinal cord injury }\end{array}$ \\
\hline 806 & Fracture of vertebral column with spinal cord injury \\
\hline 907.2 & Late effects of spinal cord injury \\
\hline 952 & Spinal cord injury without evidence of spinal bone injury \\
\hline 953 & Injury to nerve roots and spinal plexus \\
\hline 968 & Spinal cord lesion without evidence of spine injury \\
\hline \multicolumn{2}{|l|}{ ICD-IO } \\
\hline G82 & Paraplegia and tetraplegia \\
\hline $\mathrm{S} 12.0$ & Fracture of first cervical vertebrae \\
\hline SI2.I & Fracture of second cervical vertebrae \\
\hline $\mathrm{S} 12.2$ & Fracture of other cervical vertebrae \\
\hline SI2.7 & Multiple fractures of cervical spine \\
\hline SI3.0 & Traumatic rupture of cervical intervertebral disc \\
\hline SI3.2 & Dislocation of other and unspecified parts of neck \\
\hline SI3.4 & Sprain and strain of cervical spine \\
\hline SI4.0 & Concussion and edema of cervical spinal cord \\
\hline SI4.I & Other unspecified injuries of cervical spinal cord \\
\hline $\mathrm{S} 22.0$ & Fracture of thoracic vertebrae \\
\hline S23.0 & Traumatic rupture of thoracic intervertebral disc \\
\hline S23.I & Dislocation of thoracic vertebrae \\
\hline S24.0 & Concussion and edema of thoracic spinal cord \\
\hline S24. I & Other and unspecified injuries of thoracic spinal cord \\
\hline S32.0 & Fracture of lumbar vertebrae \\
\hline S33.0 & Traumatic vertebrae of lumbar intervertebral disc \\
\hline S33.I & Dislocation of lumbar vertebrae \\
\hline S34.0 & Concussions and edema of lumbar spinal cord \\
\hline S34.I & Other injury of lumbar spinal cord \\
\hline S34.3 & Injury of cauda equina \\
\hline T06.0 & $\begin{array}{l}\text { Injury of brain and cranial nerves with injuries of nerves } \\
\text { and spinal cord at neck level }\end{array}$ \\
\hline T06.l & $\begin{array}{l}\text { Injuries of nerves and spinal cord involving other } \\
\text { multiple body regions }\end{array}$ \\
\hline T09.3 & Injury of spinal cord, level unspecified \\
\hline T9l.I & $\begin{array}{l}\text { Sequelae of injuries, of poisoning and of other } \\
\text { consequences of external causes } \\
\text { - Sequelae of injuries of neck and trunk - Sequelae of } \\
\text { fracture of spine }\end{array}$ \\
\hline T91.3 & $\begin{array}{l}\text { Sequelae of injuries, of poisoning and of other } \\
\text { consequences of external causes } \\
\text { - Sequelae of injuries of neck and trunk - Sequelae of } \\
\text { injury of spinal cord }\end{array}$ \\
\hline
\end{tabular}

\section{References}

1. Pickett W, Simpson K, Walker J, Brison RJ. Traumatic spinal cord injury in Ontario, Canada. J Trauma. 2003;55(6):1070-1076.

2. McCammon JR, Ethans K. Spinal cord injury in Manitoba: a provincial epidemiological study. J Spinal Cord Med. 2011;34(1):6-10.
3. Dryden DM, Saunders LD, Rowe BH, et al. The epidemiology of traumatic spinal cord injury in Alberta, Canada. Can J Neurol Sci. 2003;30(2):113-121.

4. Lenehan B, Street J, Kwon BK, et al. The epidemiology of traumatic spinal cord injury in British Columbia, Canada. Spine (Phila Pa 1976). 2012;37(4):321-329.

5. Price C, Makintubee S, Herndon W, Istre GR. Epidemiology of traumatic spinal cord injury and acute hospitalization and rehabilitation charges for spinal cord injuries in Oklahoma, 1988-1990. Am J Epidemiol. 1994;139(1):37-47.

6. Surkin J, Gilbert BJ, Harkey HL 3rd, Sniezek J, Currier M. Spinal cord injury in Mississippi. Findings and evaluation, 1992-1994. Spine (Phila Pa 1976). 2000;25(6):716-721.

7. Thurman DJ, Burnett CL, Jeppson L, Beaudoin DE, Sniezek JE. Surveillance of spinal cord injuries in Utah, USA. Paraplegia. 1994;32(10):665-669.

8. Warren S, Moore M, Johnson MS. Traumatic head and spinal cord injuries in Alaska (1991-1993). Alaska Med. 1995;37(1):11-19.

9. Kraus JF, Franti CE, Riggins RS, Richards D, Borhani NO. Incidence of traumatic spinal cord lesions. J Chronic Dis. 1975;28(9):471-492.

10. Fine PR, Kuhlemeier KV, DeVivo MJ, Stover SL. Spinal cord injury: an epidemiologic perspective. Paraplegia. 1979;17(2):237-250.

11. Pickett GE, Campos-Benitez M, Keller JL, Duggal N. Epidemiology of traumatic spinal cord injury in Canada. Spine (Phila Pa 1976). 2006;31(7):799-805.

12. Burke DA, Linden RD, Zhang YP, Maiste AC, Shields CB. Incidence rates and populations at risk for spinal cord injury: A regional study. Spinal Cord. 2001;39(5):274-278.

13. Griffin MR, Opitz JL, Kurland LT, Ebersold MJ, O’Fallon WM. Traumatic spinal cord injury in Olmsted County, Minnesota, 1935-1981. Am J Epidemiol. 1985;121(6):884-895.

14. Minaire $P$, Demolin $P$, Bourret J, et al. Life expectancy following spinal cord injury: a ten-years survey in the Rhône-Alpes Region, France, 1969-1980. Paraplegia. 1983;21(1):11-15.

15. Divanoglou A, Levi R. Incidence of traumatic spinal cord injury in Thessaloniki, Greece and Stockholm, Sweden: a prospective populationbased study. Spinal Cord. 2009;47(11):796-801.

16. Hagen EM, Eide GE, Rekand T, Gilhus NE, Gronning M. A 50-year follow-up of the incidence of traumatic spinal cord injuries in Western Norway. Spinal Cord. 2010;48(4):313-318.

17. Martins F, Freitas F, Martins L, Dartigues JF, Barat M. Spinal cord injuries - epidemiology in Portugal's central region. Spinal Cord. 1998;36(8):574-578.

18. van Den Berg M, Castellote JM, Mahillo-Fernandez I, de Pedro-Cuesta J. Incidence of traumatic spinal cord injury in Aragón, Spain (1972-2008). J Neurotrauma. 2011;28(3):469-477.

19. Karamehmeto lu SS, Nas K, Karacan I, et al. Traumatic spinal cord injuries in southeast Turkey: an epidemiological study. Spinal Cord. 1997;35(8):531-533.

20. Rahimi-Movaghar V, Saadat S, Rasouli MR, et al. Prevalence of spinal cord injury in Tehran, Iran. J Spinal Cord Med. 2009;32(4):428-431.

21. Silberstein B, Rabinovich S. Epidemiology of spinal cord injuries in Novosibirsk, Russia. Paraplegia. 1995;33(6):322-325.

22. Chen CF, Lien IN. Spinal cord injuries in Taipei, Taiwan, 1978-1981. Paraplegia. 1985;23(6):364-370.

23. Lan C, Lai JS, Chang KH, Jean YC, Lien IN. Traumatic spinal cord injuries in the rural region of Taiwan: an epidemiological study in Hualien county, 1986-1990. Paraplegia. 1993;31(6):398-403.

24. Bracken MB, Freeman DH Jr. Hellenbrand K. Incidence of acute traumatic hospitalized spinal cord injury in the United States, 1970-1977. Am J Epidemiol. 1981;113(6):615-622.

25. Biering-Sørensen E, Pedersen V, Clausen S. Epidemiology of spinal cord lesions in Denmark. Paraplegia. 1990;28(2):105-118.

26. Sabre L, Pedai G, Rekand T, Asser T, Linnamägi U, Kõrv J. High incidence of traumatic spinal cord injury in Estonia. Spinal Cord. 2012;50(10):755-759. 
27. Ahoniemi E, Alaranta H, Hokkinen EM, Valtonen K, Kautiainen H. Incidence of traumatic spinal cord injuries in Finland over a 30-year period. Spinal Cord. 2008;46(12):781-784.

28. Albert T, Ravaud JF; Tetrafigap group. Rehabilitation of spinal cord injury in France: a nationwide multicentre study of incidence and regional disparities. Spinal Cord. 2005;43(6):357-365.

29. Pedersen V, Müller PG, Biering-Sørensen F. Traumatic spinal cord injuries in Greenland 1965-1986. Paraplegia. 1989;27(5): 345-349.

30. Knútsdóttir S, Thórisdóttir H, Sigvaldason K, Jónsson H, Björnsson A, Ingvarsson P. Epidemiology of traumatic spinal cord injuries in Iceland from 1975 to 2009. Spinal Cord. 2012;50(2):123-126.

31. O’Connor RJ, Murray PC. Review of spinal cord injuries in Ireland Spinal Cord. 2006;44(7):445-448.

32. van Asbeck FW, Post MW, Pangalila RF. An epidemiological description of spinal cord injuries in The Netherlands in 1994. Spinal Cord. 2000;38(7):420-424.

33. Gjone R, Nordlie L. Incidence of traumatic paraplegia and tetraplegia in Norway: a statistical survey of the years 1974 and 1975. Paraplegia. 1978;16(1):88-93.

34. Soopramanien A. Epidemiology of spinal injuries in Romania. Paraplegia. 1994;32(11):715-722.

35. Garcia-Reneses J, Herruzo-Cabrera R, Martinez-Moreno M. Epidemiological study of spinal cord injury in Spain 1984-1985. Paraplegia. 1991;29:180-190.

36. Pérez K, Novoa AM, Santamariña-Rubio E, et al; Working Group for Study of Injuries of Spanish Society of Epidemiology. Incidence trends of traumatic spinal cord injury and traumatic brain injury in Spain, 2000-2009. Accid Anal Prev. 2012;46:37-44.

37. Gehrig R, Michaelis LS. Statistics of acute paraplegia and tetraplegia on a national scale. Switzerland 1960-1967. Paraplegia. 1968;6(2):93-95.
38. Karacan I, Koyuncu H, Pekel O, et al. Traumatic spinal cord injuries in Turkey: a nation-wide epidemiological study. Spinal Cord. 2000;38(11): 697-701.

39. Sabre L, Hagen EM, Rekand T, Asser T, Kõrv J. Traumatic spinal cord injury in two European countries: why the differences? Eur J Neurol. 2013;20(2):293-299.

40. Otom AS, Doughan AM, Kawar JS, Hattar EZ. Traumatic spinal cord injuries in Jordan - an epidemiological study. Spinal Cord. 1997;35(4): 253-255.

41. Shingu H, Ikata T, Katoh S, Akatsu T. Spinal cord injuries in Japan: a nationwide epidemiological survey in 1990. Paraplegia. 1994;32(1): 3-8.

42. O'Connor P. Incidence and patterns of spinal cord injury in Australia. Accid Anal Prev. 2002;34(4):405-415.

43. Maharaj JC. Epidemiology of spinal cord paralysis in Fiji: 1985-1994. Spinal Cord. 1996;34(9):549-559.

44. Dixon GS, Danesh JN, Caradoc-Davies TH. Epidemiology of spinal cord injury in New Zealand. Neuroepidemiology. 1993;12(2):88-95.

45. DeVivo MJ, Fine PR, Maetz HM, Stover SL. Prevalence of spinal cord injury: a reestimation employing life table techniques. Arch Neurol. 1980;37(11):707-708.

46. Harvey C, Rothschild BB, Asmann AJ, Stripling T. New estimates of traumatic SCI prevalence: a survey-based approach. Paraplegia. 1990;28(9):537-544.

47. O’Connor PJ. Prevalence of spinal cord injury in Australia. Spinal Cord 2005;43(1):42-46.

48. Dahlberg A, Kotila M, Leppänen P, Kautiainen H, Alaranta H. Prevalence of spinal cord injury in Helsinki. Spinal Cord. 2005;43(1):47-50.
Clinical Epidemiology

\section{Publish your work in this journal}

Clinical Epidemiology is an international, peer-reviewed, open access journal focusing on disease and drug epidemiology, identification of risk factors and screening procedures to develop optimal preventative initiatives and programs. Specific topics include: diagnosis, prognosis, treatment, screening, prevention, risk factor modification, systematic

\section{Dovepress}

reviews, risk \& safety of medical interventions, epidemiology \& biostatical methods, evaluation of guidelines, translational medicine, health policies \& economic evaluations. The manuscript management system is completely online and includes a very quick and fair peer-review system, which is all easy to use. 